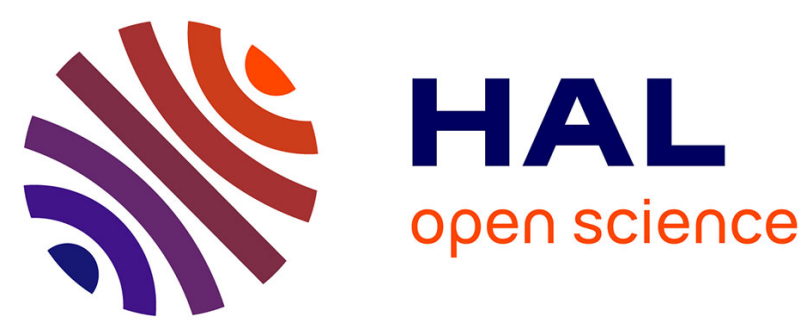

\title{
Mantle sources and magma evolution beneath the Cameroon Volcanic Line: Geochemistry of mafic rocks from the Bamenda Mountains (NW Cameroon)
}

Pierre Kamgang, Gilles Chazot, Emmanuel Njonfang, Nicaise Blaise Tchuimegnie Ngongang, Félix M. Tchoua

\section{To cite this version:}

Pierre Kamgang, Gilles Chazot, Emmanuel Njonfang, Nicaise Blaise Tchuimegnie Ngongang, Félix M. Tchoua. Mantle sources and magma evolution beneath the Cameroon Volcanic Line: Geochemistry of mafic rocks from the Bamenda Mountains (NW Cameroon). Gondwana Research, 2013, 24, pp.727741. 10.1016/j.gr.2012.11.009 . insu-00842824

\section{HAL Id: insu-00842824 \\ https://hal-insu.archives-ouvertes.fr/insu-00842824}

Submitted on 9 Jul 2013

HAL is a multi-disciplinary open access archive for the deposit and dissemination of scientific research documents, whether they are published or not. The documents may come from teaching and research institutions in France or abroad, or from public or private research centers.
L'archive ouverte pluridisciplinaire HAL, est destinée au dépôt et à la diffusion de documents scientifiques de niveau recherche, publiés ou non, émanant des établissements d'enseignement et de recherche français ou étrangers, des laboratoires publics ou privés. 
1 Mantle sources and magma evolution beneath the Cameroon Volcanic Line: Geochemistry of mafic

rocks from the Bamenda Mountains (NW Cameroon).

Pierre Kamgang ${ }^{1}$, Gilles Chazot ${ }^{2,3, *}$, Emmanuel Njonfang ${ }^{4}$, Nicaise Blaise Tchuimegnie Ngongang ${ }^{1}$, Félix M. Tchoua ${ }^{1}$

1. Département des Sciences de la Terre, Faculté des Sciences, Université de Yaoundé I, B.P. 812, Yaoundé, Cameroun.

2. Université européenne de Bretagne, France

3. CNRS, UMR 6538, domaines océaniques, institut universitaire Européen de la mer,

Université de Brest, place Copernic, 29280 Plouzané, France

4. Laboratoire de Géologie, Ecole Normale Supérieure, Université de Yaoundé I, B.P. 47, Yaoundé, Cameroun.

* Corresponding author: Gilles.Chazot@univ-brest.fr. Tel: 33.2.98.49.87.59. Fax: 33.2.98.49.87.60

\begin{abstract}
We report the mineralogy, geochemistry and geochronology of the mafic rocks from the Bamenda Mountains, part of the the Cameroon Volcanic Line (CVL), in order to discuss the origin and evolution of the magmas in this part of the CVL.

Mafic rocks in the Bamenda Mountains are basanites, basalts, hawaiites and mugearites with an alkaline affinity. K-Ar ages have been obtained on 10 samples and range from 17.6 Myr to present.

Trace element and isotopic compositions $(\mathrm{Sr}-\mathrm{Nd}-\mathrm{Pb})$ show that some samples among the oldest are slightly contaminated by a crustal component with high $\mathrm{La} / \mathrm{Nb}$ and ${ }^{87} \mathrm{Sr} /{ }^{86} \mathrm{Sr}$ ratios and low $\mathrm{Pb}$ isotopic ratios.
\end{abstract}

The mafic rocks strongly resemble OIB in their trace element compositions. Some samples possess a positive $\mathrm{Sr}$ and $\mathrm{Eu}$ anomaly which cannot be explained by a process of plagioclase accumulation. These anomalies are also observed in some pyroxenites found as xenoliths in the Adamawa volcanic province further north.

Furthermore, non-contaminated samples have high $\mathrm{Pb}$ isotopic ratios and point towards an HIMU component similar to the St Helena mantle plume. We propose that the Bamenda mafic magmas with positive $\mathrm{Sr}$ and $\mathrm{Eu}$ anomalies were formed by hybridation of asthenospheric melts with melts formed by the partial melting of pyroxenites. Samples without these anomalies result from the hybridation of 
the same asthenopheric melts with melts coming from the metasomatized, amphibole-bearing,

36 lithospheric mantle.

$\frac{1}{3} 7$

3

38

5

39

8

40

10

111

12

142 15

163 17

184 20

245

22

236 25

267

27

298

Keywords: Cameroon Volcanic Line; Bamenda Mountains; mafic lavas; crustal contamination; mantle sources; pyroxenites.

\section{Introduction}

Intraplate mafic magmatism generally has a wide chemical diversity especially in its trace element and radiogenic isotope compositions. The variations are considered to arise from chemically heterogeneous sources deep in the mantle (e.g., Stracke et al., 2005 and references therein), but the interaction between upwelling plume and the lithospheric mantle or the crust is another possibility to produce chemical diversities (e.g., Class and Goldstein, 1997; Bourdon et al., 1998; Class et al., 1998; Claude-Ivanaj et al., 1998; MacDonald et al., 2001; Lundstrom et al., 2003; Rankerburg et al., 2005; Yokayama et al., 2007), making much more complicated to fully understand magma generation processes in continental intraplate tectonic settings.

The Cameroon Volcanic Line (CVL) is a chain of 12 Cenozoic volcanic massifs running for approximately $1600 \mathrm{~km}$ from the island of Annobon in the Gulf of Guinea to Lake Chad (Fig. 1a). It can be divided into three zones: the oceanic sector (Annobon, Sao Tome and Principe), the continent/ocean boundary (c.o.b.: Bioko, Etinde and Mt. Cameroon) and the continental sector. The continental sector is marked by a trend of large massifs including the Manengouba, Bambouto, Bamenda and Oku mountains (Fig. 1b). Fitton and Dunlop (1985) found geochemical similarity in trace elements and Sr isotopes for basalts from both the oceanic and continental sectors, and suggested that these magmas are derived from sub-lithosperic depths without further interaction with the overlying lithosphere. Halliday et al. (1988, 1990), however, reported anomalously high ${ }^{206} \mathrm{~Pb} /{ }^{204} \mathrm{~Pb}$ ratios (up to 20.5) for the c.o.b. volcanoes, compared with relatively lower $(19-20){ }^{206} \mathrm{~Pb} /{ }^{204} \mathrm{~Pb}$ ratios for the oceanic and continental sector volcanoes. With the combination of other tracers such as $\mathrm{Sr}, \mathrm{Nd}$ and $\mathrm{O}$ isotopes, they demonstrated that such a high ${ }^{206} \mathrm{~Pb} /{ }^{204} \mathrm{~Pb}$ signature was created by the remelting 
and $\mathrm{U} / \mathrm{Pb}$ fractionation during melt migration in the St. Helena fossil plume head as it cooled after

63

emplacement 125 Myr ago. The study concluded that Cameroon line magmas are currently derived from a zone in the upper portions of the fossil plume in the lithospheric mantle. This model implies that the observed $\mathrm{Pb}$ isotope anomaly did not derive from metasomatized lithosphere. Recent research of helium isotopes for the CVL showed MORB-like ${ }^{3} \mathrm{He} /{ }^{4} \mathrm{He}$ ratios for the oceanic and continental sectors and HIMU-OIB-like ratios for the c.o.b. (Aka et al., 2004), which can consistently be explained by the fossil plume remelting model.

The Bamenda mountains are characterized by the predominance of felsic lavas over mafic ones (Kamgang et al., 2007; 2008; 2010). We report major elements, trace elements, ages and Sr-Nd-Pb isotopes of the Bamenda lavas in order to give further constraints on the magma generation.

\section{Geological setting}

The Bamenda Mountains are located between Lat. $5^{\circ} 40^{\prime}-6^{\circ} 10^{\prime} \mathrm{N}$ and Long. $10^{\circ} 00^{\prime}-10^{\circ} 30^{\prime} \mathrm{E}$ and culminate at $2,621 \mathrm{~m}$. They constitute with the Bambouto Mountains to the SW and the Oku massif to the NE, the three central volcanic massifs belonging to the volcanic centres of the Western Cameroon Highlands (WCH, Fig. 1c). Their basement consists of Pan-African granitoids (Toteu et al., 2001; Nzolang et al., 2003; Nzolang, 2005). The petrological and geochemical features of Bambouto Mountains and Oku massif are more or less established (Marzoli et al., 1999, 2000). The common features of these volcanic massifs are the predominance of felsic lavas over the mafic ones.

The Bamenda Mountains (Kamgang et al., 2007, 2008, 2010) are one of the most important volcanoes of the Cameroon Line in North-West Cameroon. They are mainly made up of mafic and felsic lavas with very small amounts of intermediate terms (benmoreite). Mafic lavas mostly consist of basanites, alkaline basalts, hawaiites and mugearites. 
Mineral analysis of Bamenda mafic lavas was performed using a Cameca Camebax electron

$\frac{1}{8} 8$

3

89

5

80

8

91 10

$1{ }^{2}$

microprobe at Nancy I, France $(15 \mathrm{kV}$ accelerating potential, 10-12 nA current and $10 \mathrm{~s}$ counting time per element). The main mineralogical data are given in Table 1.

38 samples have been analysed for major and trace elements. Samples were crushed in a steel jaw crusher and reduced to fine powder in agate mortars. Powders were analysed for major oxides and Sc by inductively coupled plasma-atomic emission spectrometry (ICP-AES), and for other trace elements by inductively coupled plasma-mass spectrometry (ICP-MS) at the Centre de Recherches Pétrographiques et Géochimiques (CRPG, Nancy, France). Precision is $0.5 \%$ for major elements, and variable for trace element contents: $2-5 \%$ in the range $50-150 \mathrm{ppm}, 2-10 \% \mathrm{ppm}$ in the range $10-50$ ppm, 5-25\% in the range 0-10 ppm. REEs are measured with a general precision of $5 \%$, and a precision always better than $10 \%$ (Morel, CRPG, personal communication 1997). More details about the analytical procedures can be found in Carignan et al. (2001).

$\mathrm{Sr}$ and $\mathrm{Nd}$ isotopic compositions were measured at Clermont-Ferrand, France. Sr was isolated by standard cation exchange and loaded onto a single Ta filament with phosphoric acid. Nd was isolated by cation exchange, then purified by Di-(2-ethylhexy1) phosphoric acid (HDEHP) Teflon substrate column and loaded onto Ta filaments of a triple Ta-Re-Ta filament assembly. Sr and Nd isotopic ratios were measured on a VG 54E mass spectrometer, in double collection mode. The ${ }^{87} \mathrm{Sr} /{ }^{86} \mathrm{Sr}$ ratios are normalized to ${ }^{86} \mathrm{Sr} /{ }^{87} \mathrm{Sr}=0.1194$. The ${ }^{143} \mathrm{Nd} /{ }^{144} \mathrm{Nd}$ ratios are normalized to ${ }^{143} \mathrm{Nd} /{ }^{144} \mathrm{Nd}=0.7219$. Over the period of measurements, replicate analyses of standards gave, for National Bureau of Standards (NBS) $987,{ }^{87} \mathrm{Sr} /{ }^{86} \mathrm{Sr}=0.71024 \pm 4(2 \sigma)$ and, for La Jolla, ${ }^{143} \mathrm{Nd} /{ }^{144} \mathrm{Nd}=0.51184 \pm 3(2 \sigma)$. Routine analytical blanks at Clermont-Ferrand were $<0.4 \%$ for $\mathrm{Nd}$ and $<0.03 \%$ for $\mathrm{Sr}$. $\mathrm{Pb}$ isotope ratios were measured either on a Cameca TSN 206 SA mass spectrometer or a VG 54E (Clermont-Ferrand) in single collection mode.

Ten $\mathrm{K}$-Ar radiometric ages for mafic lavas were determined from whole-rocks at the CRPG in Nancy following the procedure described in Zimmermman et al. (1985) which is summarized below or at the University of Queensland in Australia. Potassium content is determined by flame photometry 
with a lithium internal standard. Argon is extracted in a heat-resistant glass vacuum apparatus and

114 determined by isotope dilution $\left({ }^{38} \mathrm{Ar}\right.$ as tracer) using a MS20 mass-spectrometer. All samples are

measured in the static mode. Age calculations were carried out using the constants recommended by Steiger and Jäger (1977). Errors were calculated with the error equation described in Defant et al. (1992), which is derived from Mahood and Drake (1982). The dated samples fulfil the following criteria: (a) absence of secondary K-bearing minerals (phyllosilicates, zeolites) in thin section, (b) loss on ignition values lower than $3 \%$.

\section{Nomenclature and petrography}

All major-oxides have been normalized to $100 \%$ on an anhydrous basis. Data are plotted on the total alkali vs. silica diagram (Le Bas et al., 1986) with subalkaline-alkaline dividing line of Miyashiro (1978) for the purpose of classification (Fig. 2). According to this diagram, all the samples exhibit an alkaline trend. Based on whole rock major element chemical compositions only, the Bamenda samples range in composition from basanite, basalt, hawaiite to mugearite.

In the $\mathrm{Na}_{2} \mathrm{O}$ vs. $\mathrm{K}_{2} \mathrm{O}$ diagram shown in Figure 2 the Bamenda mafic lavas plot mainly in the Na-series field $\left(\mathrm{Na}_{2} \mathrm{O} / \mathrm{K}_{2} \mathrm{O}=1.54-4.25\right)$ of Middlemost (1975).

Basanite is the dominant lava type. The basanites range from porphyritic to aphyric in texture. The porphyritic varieties have abundant (10-15\%) large (up to $2 \mathrm{~mm}$ ) euhedral to subhedral clinopyroxene and olivine crystals. The phenocrysts of clinopyroxene show very complex zoning with light pink core and a lilac coloured rim. In some samples, clinopyroxenes with an olive-green to light green core, and a dark brown rim occur in addition to the clinopyroxene described above. Some large olivines show resorption and strain lamellae, and are thus interpreted as xenocrysts. The olivine xenocrysts are strongly altered to red-brown iddingsite or serpentine. They occur in basanite BA10. Subhedral to euhedral titanomagnetite occurs as inclusions in both clinopyroxene and olivine and as euhedral microcrysts in the groundmass. The aphyric basanites display mineralogy similar to porphyritic varieties with rare phenocrysts of clinopyroxenes and ubiquitous microphenocrysts $(<1$ $\mathrm{mm}$ ) of olivine, clinopyroxene, and titanomagentite. 
The groundmass is composed of plagioclase, clinopyroxene, olivine, titanomagnetite smaller than 0.05

mm occasionally coexisting with interstitial alkali feldspar and nepheline in some samples.

Basalts are porphyritic with olivine and clinopyroxene (15-20\%) as main phenocrysts (2-3mm); in some samples they coexist with plagioclase phenocrysts. Two types of clinopyroxene phenocrysts have been distinguished: mainly light pink core and lilac coloured rim and few with green core and lilac coloured rim. Microphenocrysts of olivine, pink clinopyroxene and titanomagnetite are embayed in a intergranular matrix made of clinopyroxene, plagioclase, olivine, and titanomagnetite and secondary calcite in some samples.

Hawaiites contain abundant (10-15\%) plagioclase phenocrysts (laths of 2-3 mm in size), less abundant olivine phenocrysts ( $5 \mathrm{~mm}$ in size) and smaller clinopyroxene phenocrysts sometimes with a light green core. Microphenocrysts include the above phases and titanomagnetite. Some of these lavas contain rounded quartz xenocrysts. The groundmass comprises plagioclase, olivine, clinopyroxene, Fe-Ti oxides and biotite and acicular needles of apatite in some samples.

Mugearites range from porphyritic to aphyric in texture. The porphyritic varieties (e.g., BA39) contain phenocryts of plagioclase accompanied by microphenocrysts of zoned clinopyroxene (light pink core) and more rarely olivine and Fe-Ti oxides. Olivines are mostly altered. The aphyric varieties comprise microphenocrysts of olivine and Fe-Ti oxides. The groundmass of mugearites contains plagioclase, olivine, clinopyroxene, calcite and euhedral microcrystal of apatite. Like others Bamenda mafic lavas, scarse alkali feldspars are also present in the groundmass of the mugearites.

\section{Mineral chemistry}

Olivine

The range of olivine composition is depicted in Figure 3 (Suppl. data). Olivine composition in basanites range from $\mathrm{Fo}_{61}$ to $\mathrm{Fo}_{87}$ with $0.10-0.59$ wt.\% $\mathrm{CaO}$ and $0.08-0.72$ wt.\% $\mathrm{MnO}$. In these rocks, olivine phenocryts are generally more magnesian and exhibit zoning, with Fe enrichment from core $\left(\mathrm{Fo}_{70-85}\right)$ to rim $\left(\mathrm{FO}_{67-69}\right)$. Microphenocrysts are more Fe-rich $\left(\mathrm{Fo}_{61-69}\right)$. The higher Fo contents of the observed olivine xenocrysts (Fo89-91) exceed the equilibrium value indicating their incomplete re- 
equilibration with the host magma. The more primitive character of these xenocryts, also attested by

their higher $\mathrm{Ni}$ and lower $\mathrm{Mn}$ and $\mathrm{Ca}$ contents (Suppl. data) is rather characteristic of mantle-derived olivine peridotite.

In the basalts, olivine composition ranges from $\mathrm{Fo}_{52}$ to $\mathrm{Fo}_{84}$ with $0.16-1.16$ wt.\% $\mathrm{CaO}$ and 0.15 -0.86 wt.\% $\mathrm{MnO}$. In the hawaiites, olivine composition ranges from $\mathrm{Fo}_{56}$ to $\mathrm{Fo}_{67}$ with $0.26-0.47$ wt.\% $\mathrm{CaO}$ and $0.63-0.83$ wt.\% $\mathrm{MnO}$. In the mugearites, olivine composition ranges from $\mathrm{Fo}_{42}$ to $\mathrm{Fo}_{50}$ with 0.34-1.06 wt.\% $\mathrm{CaO}$ and 0.96-1.38 wt.\% $\mathrm{MnO}$.

Although there is significant overlap in composition amongst the different groups of lavas, there is a general increase in fayalite component and $\mathrm{MnO}$ content with degree of differentiation.

Clinopyroxene

Chemical compositions of the representative Cpx analyses are shown in a ternary plot of the Wo-En-Fs system (Fig. 3; Suppl. data). All Cpx from different rock-types are Ca-rich and range from diopside to augite in composition.

Cpx in basanites ranges from $\mathrm{Wo}_{52} \mathrm{En}_{33} \mathrm{Fs}_{15}$ to $\mathrm{Wo}_{46} \mathrm{En}_{41} \mathrm{Fs}_{13}$. $\mathrm{TiO}_{2}$ (2.1-6.3 wt.\%), $\mathrm{Al}_{2} \mathrm{O}_{3}$ (3.910.2 wt.\%) and $\mathrm{Na}_{2} \mathrm{O}(0.4-0.8 \mathrm{wt} \%)$ abundances are fairly high and varied and indicate the alkali nature of these pyroxenes (Schweitzer et al., 1979). Cpx in some basanite shows both concentric and sector zoning. Sector-zoned Cpx phenocrysts show differences in $\mathrm{TiO}_{2}, \mathrm{Al}_{2} \mathrm{O}_{3}, \mathrm{FeO}$ and $\mathrm{MgO}$ contents in different sectors (Fig.4). Green cores noted in some of the larger phenocrysts are $\mathrm{Na}_{2} \mathrm{O}$ and $\mathrm{FeO}$ rich but low in $\mathrm{Al}_{2} \mathrm{O}_{3}, \mathrm{MgO}$ and $\mathrm{TiO}_{2}$ (Fig. 4). $\mathrm{Al} / \mathrm{Ti}$ ratios are low in the core (0.04-0.19) and high in the rim (0.27-0.39). The green-core Cpx belong to aluminian diopside according to the IMA classification scheme (Morimoto et al., 1988) and are fassaitic or ferrosalitic. Both types are comparatively Fe rich.

In the basalts the green $\mathrm{Cpx}$ were not analysed. Cpx range from $\mathrm{Wo}_{47} \mathrm{En}_{38} \mathrm{Fs}_{15}$ to $\mathrm{Wo}_{44} \mathrm{En}_{40} \mathrm{Fs}_{16}$. $\mathrm{TiO}_{2}$ (1.1-3.7 wt.\%), $\mathrm{Al}_{2} \mathrm{O}_{3}(1.3-6.5$ wt. $\%)$ and $\mathrm{Na}_{2} \mathrm{O}(0.00-0.05$ wt.\%) abundances are low relative to Cpx from basanites. The phenocrysts are normally zoned with decreasing $\mathrm{MgO}$ contents from the core towards the rim (Fig.4). $\mathrm{FeO}$ and $\mathrm{TiO}_{2}$ increase from core to rim. 

$\mathrm{Wo}_{50} \mathrm{En}_{36} \mathrm{Fs}_{14} . \mathrm{TiO}_{2}(1.3-3.6 \mathrm{wt} \%), \mathrm{Al}_{2} \mathrm{O}_{3}\left(2.1-4.5\right.$ wt.\%) and $\mathrm{Na}_{2} \mathrm{O}$ (0.5-1.3 wt.\%) abundances are low relative to $\mathrm{Cpx}$ from basanites. Their $\mathrm{Na}_{2} \mathrm{O}$ content is higher than that of basalts.

In mugearites, $\mathrm{Cpx}$ is augite and ranges in composition from $\mathrm{Wo}_{42} \mathrm{En}_{29} \mathrm{Fs}_{29}$ to $\mathrm{Wo}_{45} \mathrm{En}_{36} \mathrm{Fs}_{19}$.

$\mathrm{TiO}_{2}, \mathrm{Al}_{2} \mathrm{O}_{3}$ and $\mathrm{Na}_{2} \mathrm{O}$ abundances are $0.6-1.2,1.5-2.7$ and 0.3-0.5 wt. \% respectively.

Feldspars

Suppl. data). The $\mathrm{CaO}$ content (1.1-13.5, 1.8-16.4, 0.9-12.2, and 2.0-11.5 wt.\% for basanite, basalt, hawaiite and mugearite respectively) shows a wide range and the anorthite content ranges from 5.1 to 68.7 wt. $\%$ in basanites, 8.7 to 81.1 wt. $\%$ in basalts, 4.6 to 61.3 wt. $\%$ in hawaiites and 8.4 to 55.1 wt. $\%$ in mugearites. The $\mathrm{Al}_{2} \mathrm{O}_{3}$ and $\mathrm{FeO}$ contents show wide and narrow compositional ranges with 19.2$32.4 \mathrm{wt}$ \% and 0.1-1.0 wt.\%, respectively. The major-element variations (in wt. \% oxide) along rim to rim traverses across one plagioclase phenocryst from basalt BA26 are shown in Figure 4. The rim is lower in $\mathrm{Al}_{2} \mathrm{O}_{3}$ and $\mathrm{CaO}$ and higher in $\mathrm{Na}_{2} \mathrm{O}$ than the core.

The combined trend of the basanite, basalt, hawaiite and mugearite feldspars describes a classic feldspar solidus (Tuttle and Bowen, 1958), extending from calcic bytownite $\left(\mathrm{An}_{81} \mathrm{Ab}_{19} \mathrm{Or}_{0}\right)$ to sodic sanidine $\left(\mathrm{An}_{5} \mathrm{Ab}_{45} \mathrm{Or}_{50}\right)$ (Fig. 3).

Fe-Ti oxides

Titanomagnetite is the only Fe-Ti (Fe recalculated after Stormer, 1983) phase occurring in the mafic lavas of Bamenda (Suppl. data). The Titanomagnetite has variable ulvöspinel contents (49-87 mol.\%; $14.5-27.9$ wt. $\% \mathrm{TiO}_{2}$ ). $\mathrm{MnO}$ ranges from 0.4 wt. $\%$ to 1.0 wt. $\%$ and $\mathrm{Al}_{2} \mathrm{O}_{3}$ from 1.0 wt. $\%$ to 7.7 wt.\%.

\section{Feldspathoids}

Nepheline has been analysed as microlites in the basanites. Its composition (mol. \%) varies between $\mathrm{Ne}_{75} \mathrm{Ks}_{11} \mathrm{Qz}_{14}$ and $\mathrm{Ne}_{63} \mathrm{Ks}_{6} \mathrm{Qz}_{31}$ (Suppl. data). $\mathrm{Na}_{2} \mathrm{O}$ content ranges from 13.4 to 16.8 wt. \%. $\mathrm{K}_{2} \mathrm{O}$ (1.6-2.8 wt. \%) and $\mathrm{Fe}_{2} \mathrm{O}_{3}(0.3-0.9$ wt.\%) contents are low relative to nepheline of the phonolite from Upper Benue valley (4.9 and 1.8 wt.\% respectively; Ngounouno et al., 2003). 
220 Mica

$2 \frac{1}{2} 1$

3

242

$2 \frac{8}{4}$

29
8

294 10

垡5

12

136

15

整7

18

20

219

22

330

Phlogopite occurs only in hawaiites. It is characterized by high $\mathrm{MgO}$ contents, ranging between 17.6 and 20.1 wt. $\%$. The $\mathrm{FeO}$ and $\mathrm{Al}_{2} \mathrm{O}_{3}$ contents vary between 8.1-13.7 wt.\% and 11.1-12.3 wt.\% respectively. It has low $\mathrm{Na}_{2} \mathrm{O}\left(0.9-1.1\right.$ wt.\%) and $\mathrm{CaO}\left(0.03-0.4\right.$ wt.\%), with $\mathrm{TiO}_{2}$ contents between 3.6 and $5.2 \mathrm{wt} . \%$ (Suppl. data).

\section{Results}

\subsection{Geochemistry}

\subsubsection{Major element geochemistry}

In this paper we focus on the most mafic lavas of the Bamenda volcanic province. The major elements (Table 8) data show that these rocks have $\mathrm{SiO}_{2}$ ranging from 41 to 52 wt. $\%, \mathrm{MgO}$ from 2.5 to 11.0 wt. $\%$ and $\mathrm{CaO}$ from 5.3 to $12.7 \mathrm{wt} . \%$. $\mathrm{TiO}_{2}$ is high, ranging from 2 to $4.4 \mathrm{wt} . \%$.

The $\mathrm{Mg}$-number values $[\mathrm{Mg} \#=100 * \mathrm{MgO} /(\mathrm{MgO}+\mathrm{FeO})$, atomic ratio, assuming that $\left.\mathrm{Fe}_{2} \mathrm{O}_{3} / \mathrm{FeO}=0.15\right]$ lie between 25 and 62 , and mostly correlate with major element contents showing fairly coherent trends (Fig. 5). These values mean that the magmas cannot be primary. For $\mathrm{SiO}_{2}$, $\mathrm{Al}_{2} \mathrm{O}_{3}, \mathrm{Na}_{2} \mathrm{O}$ and $\mathrm{K}_{2} \mathrm{O}$, the correlations are negative and, for $\mathrm{CaO}$, positive. However, some samples with $\mathrm{Mg} \#$ between 45 to 62 show narrow range of $\mathrm{CaO}$ contents $\left(8-10\right.$ wt.\%). $\mathrm{TiO}_{2}$ increases when Mg\# decreases from 55 to 45 and then decreases when Mg\# is lower than 45. These variations may correspond to those expected from fractional crystallization process, even though plots are scattered. This scatter is probably partly due to the large range of age of the studied samples (from $28 \mathrm{Ma}$ to present for the whole Bamenda lavas) implying that we are observing different differentiation trends from different parental magmas.

\subsubsection{Trace element geochemistry}

Compatible trace element geochemistry 
Trace element data are listed in Table 2. Sc, Cr, Co, Ni and V behave compatibly in the

246

$2 \frac{1}{2} 7$

3

248

5

299

8

290

17

12

13

15

293

18

衫4

20

$2 \$ 5$

22

2356

Bamenda basaltic lavas (decrease with falling $\mathrm{Mg \# ).} \mathrm{The} \mathrm{less} \mathrm{evolved} \mathrm{rocks} \mathrm{(Mg \#} \mathrm{>} \mathrm{55)} \mathrm{have} \mathrm{high} \mathrm{Cr}$ and $\mathrm{Ni}$ contents ranging up to 556 and $283 \mathrm{ppm}$ respectively, but lower than the values assumed for primary magmas (Ni: 300-400 ppm; Cr: 300-500 ppm; Co: 50-70 ppm; e.g., Frey et al., 1978; Jung and Masberg, 1998). The more evolved samples ( $\mathrm{Mg \#} \mathrm{<} \mathrm{55)} \mathrm{have} \mathrm{low} \mathrm{Cr}$ and $\mathrm{Ni}$ contents ranging down to 0.70 and $1.54 \mathrm{ppm}$ respectively. In Fig. $6 \mathrm{a}$, b, the rocks define a hyperbolic trend presumably reflecting crystal fractionation with the removal of olivine + pyroxene \pm spinel assemblage.

Incompatible trace element geochemistry

Harker variation diagrams of trace elements are plotted vs. $\mathrm{SiO}_{2}$ (Fig. 6). As a whole, plots are scattered. The best correlation is exemplified by $\mathrm{Zr}$ which correlates positively with $\mathrm{SiO}_{2}$. These trends may be related to the fractional crystallization processes (Fig. 6). Again, the scattering in the diagrams may be due to the presence of several differentiation trends through time.

Distinct incompatible trace elements characteristics of these rocks include: large variation of total rare earth elements ( $\mathrm{REE})$ contents $(135-401 \mathrm{ppm})$ and trace element ratios such as $\mathrm{Nb} / \mathrm{La}(0.9$ - 1.5) and $\mathrm{Ba} / \mathrm{Nb}(7.3-21.7)$. Several other key parameters are: $\mathrm{Ba} / \mathrm{Nb}=7.3-21.7, \mathrm{Ce} / \mathrm{Pb}=20.0-$ 42.0, $\mathrm{Nb} / \mathrm{U}=33.2-81.3, \mathrm{Th} / \mathrm{La}=0.06-0.13$ and $\mathrm{Zr} / \mathrm{Nb}=2.8-6.1$.

Chondrite-normalized REE patterns of the Bamenda samples (Fig. 7a-d) exhibit light REE (LREE) enrichment relative to heavy REE (HREE) with $(\mathrm{La} / \mathrm{Yb}) \mathrm{n}$ (where the subscript $\mathrm{n}$ means chondrite-normalized) ranging from 10.7 to 22.8 . All the analysed samples show positive europium anomalies $\left(\mathrm{Eu} / \mathrm{Eu}^{*}=1.1-1.4\right.$, where $\mathrm{Eu}$ is normalized $\mathrm{Eu}$ and $\mathrm{Eu}^{*}$ is $\mathrm{Eu}$ interpolated between normalized $\mathrm{Sm}$ and $\mathrm{Gd}$ : $\left.\mathrm{Eu}^{*}=\left(\mathrm{Sm}_{\mathrm{n}} \mathrm{xNd} \mathrm{n}_{\mathrm{n}}\right)^{1 / 2}\right)$. In the absence of any cumulus textures and positive correlation between $\mathrm{Al}_{2} \mathrm{O}_{3}$ and $\mathrm{Eu}$ anomaly, we argue that the positive $\mathrm{Eu}$ anomalies in these mafic lavas are an original geochemical feature of the melts rather than a result of plagioclase accumulation. Chondrite-normalized $\mathrm{Tb} / \mathrm{Yb}$ values (1.8-3.0) are roughly constant among the Bamenda samples, and overlap values for Mount Cameroon (Yokoyama et al., 2007), Ngaoundéré volcanism (Nkouandou et al., 2008) and alkali lavas of Nyos (Aka et al., 2004). This ratio is a good indicator of residual garnet 
272 in the mantle source of the basalts, thus suggesting that Bamenda primary magmas have been formed

273 by melting in the presence of garnet. REE patterns of N-MORB, E-MORB and OIB (Sun and

$2 \frac{1}{2} 4$ 3 245 5 296 8 297 10 瑟8 12

McDonough, 1989) are also illustrated in Fig. 7. All Bamenda samples are above those of N-MORB and E-MORB and strongly resemble that of OIB.

Incompatible trace elements are very complex as can be seen in primitive mantle normalized incompatible trace elements diagrams (Fig. 8a, b, c, d). All the Bamenda mafic lavas show high concentrations of highly incompatible large ion elements ( $\mathrm{Ba}, \mathrm{Rb}, \mathrm{Th}, \mathrm{U})$ relative to moderately incompatible elements (e.g., Ti and HREE). The Bamenda mafic lavas have positive $\mathrm{Nb}$ and $\mathrm{Ta}$ anomalies and $\mathrm{K}, \mathrm{P}$ and $\mathrm{Ti}$ negative anomalies. Basanites, basalts and hawaiites show positive $\mathrm{Sr}$ anomalies whereas mugearite shows negative anomalies. Mantle-normalized $\mathrm{Ce} / \mathrm{Pb}$ ratios in Bamenda mafic lavas are greater than 1, which is typical of plume-derived magmas (e.g., Tian et al., 2010).

\subsection{Geochronology}

The K-Ar data are presented in the Table 3. The ages range from 17.6 Ma to Present. Even if these ages are not representative of the whole volcanic area, they show that mafic volcanism exists over a long period of time and is partly coeval with the felsic volcanism (from 27 to $12 \mathrm{Ma}$, Kamgang et al., 2007). However, very recent ages obtained on some mafic rocks have not been found among the felsic ones. The age of the mafic volcanism of the Bamenda area is consistent with ages measured for the volcanism of the other volcanic provinces from the Oku massif to the North to the still active Mount Cameroon to the South (Déruelle et al., 2007). Consequently, volcanism in the Bamenda Mountains exists over a more than 25 Myr period, with no displacement of the volcanic centers through time.

\section{3. $\mathrm{Sr}, \mathrm{Nd}$ and $\mathrm{Pb}$ isotope geochemisty}

The results of $\mathrm{Sr}, \mathrm{Nd}, \mathrm{Pb}$ isotope analyses are given in Table 4. The effects of age correction for radioactive decay are small for our samples because $\mathrm{Rb} / \mathrm{Sr}$ and $\mathrm{Sm} / \mathrm{Nd}$ are low. Almost all of the samples display positive $\varepsilon \mathrm{Nd}$ values ranging from +1.85 to +5.07 , typical of mantle-derived magmas (Table 4 and Fig. 9a), the only exception being sample BA60, which shows $\varepsilon \mathrm{Nd}=-0.40$. 
As shown in a diagram of $\varepsilon \mathrm{Nd}$ vs. ${ }^{87} \mathrm{Sr} /{ }^{86} \mathrm{Sr}$ (Fig. 9a), the Bamenda mafic lavas plot in the "depleted

300

$3 \frac{1}{21}$

3

392

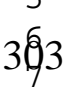

304 10

325

field" relative to bulk silicate Earth (BSE). The higher ${ }^{143} \mathrm{Nd} /{ }^{144} \mathrm{Nd}$ than Bulk Earth in all Bamenda mafic lavas (except BA60) implies a time-integrated depletion of the source of the magmas. Generally, this trend is similar to trends of other mafic alkaline rocks from the CVL (Halliday et al., 1988, 1990; Lee et al., 1994; Marzoli et al., 2000; Rankenburg et al., 2005; Yokoyama et al., 2007; Nkouandou et al., 2008; Nkouathio et al., 2008). These $\varepsilon_{\text {Nd }}$ values are less variable than those of xenoliths of CVL (1.4 to +17 ; Lee et al., 1996) but are in the range of clinopyroxene and plagioclase megacrysts (+3.0 to 6.4; Lee et al., 1996; Rakenburg et al., 2005). Some samples of Bamenda mafic lavas with $\varepsilon$ Nd $>4.0$ and ${ }^{87} \mathrm{Sr} /{ }^{86} \mathrm{Sr}$ of $0.7031-0.7033$ fall into the field of FOZO (focal zone) (Hart et al., 1992) recently redefined by Stracke et al. (2005), or "C" (Hanan and Graham, 1996). This field is similar or slightly more radiogenic in its $\mathrm{Sr}$ composition than HIMU mantle (HIMU $=$ high $\mu ; \mu={ }^{238} \mathrm{U} /{ }^{204} \mathrm{~Pb}$; e.g., Zindler and Hart, 1986; Hofmann, 1997). Sample BA60 $\left({ }^{87} \mathrm{Sr} /{ }^{86} \mathrm{Sr}=0.7042\right.$ and ${ }^{143} \mathrm{Nd} /{ }^{144} \mathrm{Nd}=$ $0.51261)$ plots towards the field of enriched mantle. Its composition is similar to EM1 $(\mathrm{EM}=$ enriched mantle; Zindler and Hart, 1986). Some data of Bambouto (Lee et al., 1994; Marzoli et al., 2000) and from Oku (Marzoli et al., 2000) indicate minor contribution of EM1.

These isotopic data overlap with the isotopic composition of OIB, and plot around or slightly above the low Nd (LoNd) array (Hart, 1984) in the ${ }^{206} \mathrm{~Pb} /{ }^{204} \mathrm{~Pb}$ vs. ${ }^{87} \mathrm{Sr} /{ }^{86} \mathrm{Sr}$ plot (Fig. 9b) except two samples. Samples BA60 and BA41 plot below the LoNd array whereas sample BA60 plots around EM1. ${ }^{206} \mathrm{~Pb} /{ }^{204} \mathrm{~Pb}$ isotopic ratio is positively correlated with ${ }^{143} \mathrm{Nd} /{ }^{144} \mathrm{Nd}$ (Fig. 9c). In the ${ }^{206} \mathrm{~Pb} /{ }^{204} \mathrm{~Pb}$ vs ${ }^{207} \mathrm{~Pb} /{ }^{204} \mathrm{~Pb}$ correlation plots (Fig. 9 d), six samples plot below the LoNd array and around the North Hemisphere Reference Line (NHRL) (Hart, 1984); three samples plot below the NHRL. All the samples show a linear trend between HIMU and EM1 components.

\section{Discussion}

\subsection{Crustal contamination}

Continental alkaline basalts are often enriched in trace-elements, with different isotopic ratios relative to their oceanic counterparts and the debate continues as to the importance of processes operating at 
crustal levels. Given the continental environment in which the alkaline lavas of Bamenda erupted, it is

327

$3 \frac{1}{2} 8$

3

349

5

$3 \frac{9}{9} 0$

8

391 10

裂2

13

重3 15

394 17

185 20

336

22

237

essential to evaluate the possible effects of crustal contamination which may have affected the ascending magmas. Such crustal contamination processes associated with the differentiation of the magmas (AFC process) have already been observed in the other volcanic massifs of the CVL (Halliday et al., 1988; Marzoli et al., 2000; Rankenburg et al., 2005) and have been well exemplified in the felsic rocks of the Bamenda Mountains associated to the studied mafic lavas (Kamgang et al., 2007).

As it is evident from the diagrams of the figure 10 , when $\mathrm{MgO}$ decreases by crystal fractionation process, $\mathrm{La} / \mathrm{Nb}$ and ${ }^{87} \mathrm{Sr} /{ }^{86} \mathrm{Sr}$ ratios increase, suggesting a contamination process by a high $\mathrm{La} / \mathrm{Nb}$ ${ }^{87} \mathrm{Sr} /{ }^{86} \mathrm{Sr}$ component, characteristic of the upper continental crust. The most primitive lavas $(\mathrm{MgO}>6$ wt. \%) have ${ }^{87} \mathrm{Sr} /{ }^{86} \mathrm{Sr}$ ratios between 0.703 and 0.7034 and $\mathrm{La} / \mathrm{Nb}$ ratios lower than 0.8 while the most differentiated rocks $(\mathrm{MgO}<6 \%)$ have ${ }^{87} \mathrm{Sr} /{ }^{86} \mathrm{Sr}$ ratio between 0.7038 and 0.7042 and $\mathrm{La} / \mathrm{Nb}$ ratio higher than 0.85 . Among the more differentiated samples are those with the lowest $\mathrm{Pb}$ isotopic ratios, suggesting that the crustal contaminant has low $\mathrm{Pb}$ isotopic composition, as already observed along the CVL by Halliday et al. (1988) but with less extreme compositions.

An important point is the strong correlation between the ${ }^{87} \mathrm{Sr} /{ }^{86} \mathrm{Sr}$ and the age of the samples (Fig. 11), also observed for the ${ }^{143} \mathrm{Nd} /{ }^{144} \mathrm{Nd}$ and the $\mathrm{La} / \mathrm{Nb}$ ratios. This correlation indicates that the crustal contamination process became less and less important through time in the Bamenda Mountains. Different mechanisms can account for this time evolution. The country rocks can become more and more refractory with time and can be isolated from the circulating magmas due to the crystallization of the previous magmas in the conduit, or a change in the extensional regime of the whole area can facilitate the circulation of the magmas through the crust, thus preventing interactions of these magmas with the country rocks. Whatever the reason for this time evolution, this implies that the most recent volcanic rocks of the Bamenda province are the most interesting to study the nature and the composition of their mantle source because they are the least contaminated by the overlying crustal rocks. 
354 Variations seen on Harker diagrams for most Bamenda mafic rocks (Fig. 5, 6), such as moderate $\mathrm{MgO}$

$3 \frac{1}{2} 5$

3

contents $(\mathrm{Mg \#} \leq 62)$, and $\mathrm{Ni}(1.54-283 \mathrm{ppm})$ and $\mathrm{Cr}(0.70-556 \mathrm{ppm})$ variations imply the occurrence of some fractional crystallization, as primary magmas in equilibrium with mantle olivine are assumed to have Mg\# values of 68-72 and high Ni (300-500 ppm), Cr (300-500 ppm) and Co (50-70ppm) contents (Frey et al., 1978, Jung and Masberg, 1998). Only the basanite sample BA68 have Mg\# value of 61 and high $\mathrm{Ni}$ and $\mathrm{Cr}$ contents (283 and 339 ppm respectively), commensurate with a (near-) primary character.

A strong decrease of the $\mathrm{Ni}$ and $\mathrm{Cr}$ concentrations when the Mg\# decreases (Fig. 6a, b) suggests the fractionation of olivine and clinopyroxene. This is confirmed by the decrease of the $\mathrm{CaO}$ content of the more differentiated magmas, associated to an increase of the $\mathrm{SiO}_{2}$ content. However, the constant increase of the $\mathrm{Al}_{2} \mathrm{O}_{3}$ during the differentiation indicates that crystallization of plagioclase was very limited in these samples.

As shown in Figure 4, some basanites contain green-core clinopyroxenes which are evidence for highpressure fractionation at an early stage of the magma evolution (e.g. Duda and Schmincke, 1985; Jung and Hoernes, 2000; Haase et al., 2004; Jung et al., 2006). This can be related to the absence of plagioclase fractionation as shown by the constant increase in $\mathrm{Al}_{2} \mathrm{O}_{3}$ in the course of fractional crystallization and could indicate that most of the magma evolution in Bamenda occurs at great depth in the upper mantle or the lower crust.

Of course, the large age range span by the Bamenda volcanic rocks implies that we are not dealing with a single differentiation trend, and thus precludes any modelling of the fractional crystallization process.

\subsection{Mantle source of Bamenda mafic lavas}

Despite evidences of crustal contamination of some of the mafic magmas before their emplacement at the surface, several observations can be emphasized in order to discuss the nature and composition of 
the mantle source of the magmas in the general framework of the CVL, with a special emphasize to

380 the most recent rocks $(<5 \mathrm{Ma})$ which are not significantly affected by the contamination process.

$3 \frac{1}{2} 1$ 3

In the $\mathrm{Zr}$-Th diagram (Fig. 12) basanites plot on a distinct correlation line, thus calling for subtle differences in the source composition or in the magma genesis process for these rocks, while no difference in the isotopic composition between the basanites and the other mafic rocks is observed (Fig. 9).

An important issue to be considered is whether the garnet is a residual phase in the source or not. The existence of residual garnet results in depletion of HREE relative to LREE because of the strong retention of HREE in garnet, as indicated by high partition coefficients of those elements in garnet (e.g. Green et al., 1989; Jenner et al., 1994). The alkaline affinity of the Bamenda mafic lavas is supported by their enrichments in incompatible elements and high fractionation indexes, $(\mathrm{La} / \mathrm{Yb})_{\mathrm{n}}$, which range from 10.62 to 22.80 . These high values of the fractionation index correspond to depletion in HREE relative to LREE (otherwise, LREE enrichment) and indicate the presence of garnet as a residual phase in the sources of these rocks. It must also be noted that the $(\mathrm{Tb} / \mathrm{Yb})_{\mathrm{n}}$ ratios (1.8-3.0) of the Bamenda mafic lavas are high and in the range of values considered to be characteristics of the presence of residual garnet in the mantle source (Wang et al., 2002). However, no difference of this ratio is observed between the basanite and the other mafic lavas, so their chemical differences evidenced from the $\mathrm{Zr}-\mathrm{Y}$-Th content is not to be related to the amount of residual garnet in their respective mantle sources.

Most of the studied samples show positive $\mathrm{Eu}$ and $\mathrm{Sr}$ anomalies without evidence for plagioclase accumulation. This feature is not correlated with the Sr isotopic composition of the rocks, so cannot be related to the crustal contamination process as some of the basanites with the highest Eu anomaly have also low Sr isotopic composition $\left({ }^{87} \mathrm{Sr} /{ }^{86} \mathrm{Sr}<0.7034\right)$. No correlation exists between these anomalies and the $\mathrm{Al}$ or $\mathrm{Ca}$ content of the lavas, thus precluding cryptic assimilation of plagioclase-rich cumulates in a magma chamber. The occurrence of such lavas at different places and times along the CVL argue also against this assimilation phenomenon. 
According to these observations, these chemical anomalies are related to the primary composition of the mafic magmas, and so has something to deal with the composition of the mantle source.

Two series of rocks, one with high Sr contents and another one with low Sr concentrations have already been observed in the mafic rocks from the nearby Bambouto volcanic province (Marzoli et al., 2000).

The existence of these two rocks series with different trace element composition (one with Eu and $\mathrm{Sr}$ positive anomalies, and one without theses anomalies) but with similar isotopic ratios implies that two mantle sources with different trace element compositions but similar isotopic ratios have contributed to their genesis. This trace element difference can be attributed to differences in the mineralogy of the source. For the Bambouto volcanic province, the high Sr rock series has been explained by the partial melting of an amphibole-bearing metasomatized mantle source (Marzoli et al., 2000).

Such a metasomatized mantle has already been observed in Cameroon and especially in mantle xenoliths from the Nyos volcano where amphibole-bearing spinel lherzolites have been described (Temdjim et al., 2004). The high Sr and Ba contents of amphiboles in these mantle samples, as well as their low $\mathrm{Zr}$ and Hf contents (Fig. 13a) make them potential candidates for the source of the high-Sr mafic magmas. However, these amphiboles do not show the high Eu content observed in the Bamenda mafic rocks and their participation to the genesis of these magmas do not explain the positive Eu anomalies. The pyroclastic deposits from the Youkou volcano in the Adamawa volcanic field contain mantle xenoliths and especially garnet-bearing pyroxenites. Whole rock chemical composition of these samples (France et al., submitted) shows that they are enriched in $\mathrm{Sr}$ and $\mathrm{Ba}$ and also possess a positive Eu anomaly in their REE patterns (Fig. 13b), as well as low $\mathrm{Zr}$ and Hf contents. Furthermore, the $\mathrm{Sr}$ and $\mathrm{Nd}$ isotopic composition of the pyroxenite xenoliths is not very different from that measured in the Bamenda mafic volcanic rocks. Partial melting of these pyroxenites and mixing of these magmas with magmas generated in associated garnet lherzolites can explain the chemical and isotopic characteristics of the Bamenda volcanic rocks. These pyroxenites also contain apatite, which is in good agreement with the observation that the Bamenda basalts with the highest Eu and $\mathrm{Sr}$ anomalies also have the highest $\mathrm{P}_{2} \mathrm{O}_{5}$ contents. The similarity of the isotopic compositions of the two 
different kinds of mafic rocks in the Bamenda Mountains is consistent with a recent origin for the

433

$4 \frac{1}{2} 4$

3

435

5

$4 \frac{6}{9} 6$

8

497 10

特8

13

429 15

490 17

栘 1

mantle source enriched in $\mathrm{Eu}, \mathrm{Sr}$ and $\mathrm{Ba}$ or a time evolution of the source with low $\mathrm{Rb} / \mathrm{Sr}$ and moderate $\mathrm{Sm} / \mathrm{Nd}$ ratios, which is the case for the Youkou pyroxenites.

In the different isotopic diagrams of the figure 9, the Bamenda mafic rocks form a linear array stretching from a low $\mathrm{Sr}$ and high $\mathrm{Nd}$ and $\mathrm{Pb}$ isotopic ratio component close to the HIMU mantle composition to a high $\mathrm{Sr}$ and low $\mathrm{Nd}-\mathrm{Pb}$ isotopic ratio component. This last component probably represents the composition of the local continental crust and highlights the crustal contamination processes which have affected some of these samples. On the other hand, the high $\mathrm{Pb}$ isotopic composition component has already been discussed and is commonly related to the enrichment of the subcontinental lithospheric mantle by metasomatic fluids originated from the St Helena mantle plume, or to the direct incorporation of the St Helena plume material into the lithospheric mantle. All the geochemical data acquired on the CVL are consistent with an origin of the magmas from the mixing between asthenopheric melts and HIMU-type melts formed by partial melting of the lithospheric mantle (Halliday et al., 1988; Marzoli et al., 2000; Rankensburg et al., 2005; Yokoyama et al., 2007).

Our data are consistent with the involvement of such an HIMU mantle component in the genesis of the Bamenda mafic rocks all along the $25 \mathrm{Ma}$ of duration of the volcanism in this province. Furthermore, the presence of the $\mathrm{Sr}$ and Eu anomalies in most of the Bamenda rocks allows us to constrain the nature of the St Helena plume fingerprint in the mantle. As shown before, these trace element anomalies have been observed in garnet pyroxenites from the Youkou volcano in the CVL. France et al. (submitted) have interpreted these pyroxenites as the crystallization at mantle depth of magmas formed by melting of the St Helena mantle plume. From our data, we can argue that the high Sr-Eu volcanic rocks of the CVL are probably formed by the interaction of asthenospheric melts with melts produced by the partial melting of garnet pyroxenites resulting from the crystallization of mafic magmas formed at the time when the St Helena was below this area of the CVL. Magmas without these $\mathrm{Sr}$ and $\mathrm{Eu}$ anomalies but with similar isotopic composition are probably the result of interaction between asthenospheric melts and melts formed by the melting of a metazomatized lithospheric mantle as already noticed in the other volcanic provinces of the CVL. The Bamenda mafic rocks allow for the 
first time to evidence the participation of old pyroxenitic veins in the genesis of magmas along the

460 CVL.

$4 \frac{1}{2} 1$

3

462

8. Conclusion

493

- Mafic magmas from the Bamenda Mountains range from basanites and hawaiites to basalts and 464 10

- They were emplaced on a large time range from 18 Ma to very recent time but despite this large time range, there are no important chemical differences between the oldest and the youngest mafic rocks.

- Some samples, especially the oldest ones, show some evidences of contamination during interaction with the continental crust.

- As a whole, the Bamenda mafic rocks were formed in the garnet stability field and resemble OIB generated above a mantle plume, but some rocks show Eu and $\mathrm{Sr}$ positive anomalies not related to plagioclase accumulation. These peculiar chemical features are consistent with the partial melting of garnet pyroxenites similar to that found as xenoliths in the Adamawa region and which possess the same chemical characteristics as well as similar isotopic composition.

- We propose that the magmas with $\mathrm{Eu}$ and $\mathrm{Sr}$ anomalies are generated by interactions of asthenospheric melts with melts formed by the melting of such garnet pyroxenites, while the other magmas are formed by the partial melting of metasomatized lherzolites. The pyroxenites probably represent melts crystallized at mantle depth when the St Helena mantle plume was active in this region.

Acknowledgements. We thank the service of the French Cooperation in Cameroon for the financial support for chemical analyses. Andy Saunders and an anonymous reviewer are thanked for their interesting and constructive remarks. Advices from the Editor Inna Safonova also greatly improved the quality of the manuscript.

\section{References}


Aka, F.T., Nagao, K., Kusakabe, M., Sumino, H., Tanyileke, G., Ateba, B., Hell, J., 2004. 488 Symmetrical helium isotope distribution on the Cameroon Volcanic Line, West Africa. Chemical 4 Geology 203, 205-223.

Bourdon, B., Joron, J.-L., Claude-Ivanaj, C., Allègre, C.J., 1998. U-Th-Pa-Ra systematics for the Grande Comore volcanics: melting processes in an upwelling plume. Earth and Planetary Science Letters 164, 119-133.

Carignan, J., Hild, P., Mévelle, G., Morel, J., Yeghicheyan, D., 2001. Routine analyses of trace elements in geological samples using flow injection and low pressure on-line liquid chromatography couples to ICPMS: a study of geochemical reference materials BR, DR-N, UB-N, AN-G and GH. Geostandards Newsletter 25, 187-198.

Class, C., Golsdstein, S.L., 1997. Plume-lithosphere interactions in the ocean basins: constraints from the source mineralogy. Earth and Planetary Science Letters 150, 245-260.

Class, C., Golsdstein, S.L., Altherr, R., Bachelery, P., 1998. The process of plume-lithosphere interactions in the ocean basins- the case of Grande Comore. Journal of Petrology 39, 881-903.

Claude-Ivanaj, C., Bourdon, B., Allègre, C.J., 1998. Ra-Th-Sr-isotope systematics in Grande Comore Island: a case study of plume-lithosphere interaction. Earth and Planetary Science Letters 164, 99-117.

Condie, K.C., 2005. High field strength element ratios in Archean basalts: a window to evolving sources of mantle plumes? Lithos 79, 491-504.

Defant, M.J., Jackson, T.E., Drummond, M.S., De Boer, J.Z., Bellon, H., Feigenson, M.D., Maury, M.C., Stewart, R.H., 1992. The geochemistry of young volcanism throughout western Panama and southeastern Costa Rica: an overview. Journal of the Geological Society London 149, 569-579

Déruelle, B., Ngounouno, I., Demaiffe, D., 2007. The "Cameroon Hot Line" (CHL): a unique example of active alkaline intraplate structure in both oceanic and continental lithospheres Comptes Rendus Géoscience 339, 589-600.

Duda, A., Schmincke, H. U., 1985. Polybaric differentiation of alkali basaltic magma: evidence from green-core clinopyroxenes (Eifel, Germany). Contributions to Mineralogy and Petrology 91, 340-351.

Emery, K.O., Uchupi, E., 1984. The Geology of the Atlantic Ocean. Springer-Verlag, New York.

Fitton, J.G., Dunlop, H.M., 1985. The Cameroon Line, West-Africa, and its bearing on the origin of Oceanic and Continental alkali basalt. Earth and Planetary Science Letters 72, 23-38.

Fitton, J.G., Saunders, A.D., Norry, M.J., Hardarson, B.S., Taylor, R.N., 1997. Thermal and chemical structure of the Iceland plume. Earth and Planetary Science Letters 153, 197-208.

Frey, F.A., Green, D.H., Roy, S.D., 1978. Integrated models of basalts petrogenesis: a study of quartz tholeiites to olivine melilites from South Eastern Australia utilizing geochemical and experimental petrological data. Journal of Petrology 19, 463-513.

Green, T.H., Sie, S.H., Ryan, C.G., Cousens, D.R., 1989. Proton microprobe determined partitioning of $\mathrm{Nb}, \mathrm{Ta}, \mathrm{Zr}, \mathrm{Sr}$ and $\mathrm{Y}$ between garnet, clinopyroxene and basaltic magma at high pressure and temperature. Chemical Geology 74, 201-216. 
Haase, K. M., Goldschmidt, B., Garbe-Schönberg, D., 2004. Petrogenesis of Tertiary continental intra-

Halliday, A.N., Dickin, A.P., Fallick, A.E., Fitton, J.G., 1988. Mantle dynamics: a Nd, Sr, Pb and O isotopics study of the Cameroon line volcanic chain. Journal of Petrology 29, 181-211.

Halliday, A.N., Davidson, J.P., Holden, P., DeWolf, C., Lee, D.-C, Fitton, J.G., 1990. Trace-element fractionation in plumes and the origin of HIMU mantle beneath the Cameroon line. Nature 347, 523528.

Hamelin, B., Allègre, C.J., 1985. Large scale regional units in the depleted upper mantle revealed by an isotopic study of the south-west India ridge. Nature 315, 196-198.

Hanan, B.B., Graham, D.W., 1996. Lead and Helium isotope evidence from oceanic basalts for a common deep source of mantle plumes. Science, 272: 991-995.

Hart, S.R., 1984. The Dupal anomaly: a large-scale isotopic anomaly in the southern hemisphere. Nature 309, 753-756.

Hart, S.R., 1988. Heterogeneous mantle domains: signatures, genesis, and mixing chronologies. Earth and Planetary Science Letters 90, 273-296.

Hart, S.R., Hauri, E.H., Oschmann, L.A., Whitehead, J.A., 1992. Mantle plumes and entrainment: isotopic evidence. Science 256, 517-520.

Hawkesworth, C.J., Rogers, N.W., Vancalsteren, P.W.C., 1984. Mantle enrichment processes. Nature 311, 331-335.

Hoffman, A., 1997. Mantle geochemistry: the message from oceanic volcanism. Nature 389, 219-229.

Jenner, G.A., Foley, S.F., Jackson, S.E., Green, T.H., Fryer, B.J, Longerich, H.P., 1994. Determination of partition coefficients for trace elements in high pressure-temperature experimental run products by laser ablation microprobe-inductively coupled plasma mass spectrometry (LAM-ICP-MS). Geochimica et Cosmochimica Acta 58, 5099-5130.

Jung, S., Masberg, P., 1998. Major and trace element systematics and isotope geochemistry of Cenozoic mafic volcanic from the Vogelsberg (Central Germany): constraints on the origin of continental alkaline and tholeiitic basalts and their mantle sources. Journal of Volcanology and Geothermal Research 86, 151-177.

Jung, S., Hoernes, S., 2000. The major- and trace element and isotope (Sr, Nd, O) geochemistry of Cenozoic alkaline rift-type volcanic rocks from the Rhön area (central Germany): petrology, mantle source characteristics and implications for asthenosphere-lithosphere interactions. Journal of Volcanology and Geothermal Research 99, 27-53.

Jung, C., Jung, S., Hoffer, E., Berndt, J., 2006. Petrogenesis of Tertiary Mafic Alkaline Magmas in the Hocheifel, Germany. Journal of Petrology 47, 1637-1671.

Kamgang, P., Njonfang, E., Chazot, G., Tchoua, F., 2007. Géochimie et géochronologie des laves felsiques des Monts Bamenda (Ligne Volcanique du Cameroun). Comptes Rendus Géoscience 339, $659-666$. 
Kamgang, P., Chazot, G., Njonfang, E., Tchoua, F., 2008. Geochemistry and geochronology of mafic rocks from Bamenda Mountains (Cameroon): Source composition and crustal contamination along the Cameroon Volcanic Line. Comptes Rendus Geoscience 340, 850-857.

Kamgang, P., Njonfang E., Nono, A., Gountie D.M., Tchoua, F., 2010. Petrogenesis of a silicic magma system: Geochemical evidence from Bamenda Mountains, NW Cameroon, Cameroon Volcanic Line. Journal of African Earth Sciences 58, 285-304

Kampunzu, A.B., Popoff, M., 1991. Distribution of the main Phanerozoic African rifts and associated magmatism, introductory notes. In: Kampunzu, A.B., Lubala, R. (Eds.), Magmatism in Extensional Structural Settings, The Phanerozoic African Plate. Springer, Berlin, New York, Heidelberg, pp. 2-10.

Le Bas, M., Le Maitre, R., Streckeisen, A., Zanettin, B., 1986. A chemical classification of volcanic rocks based on the total alkali-silica diagram. Journal of Petrology 27, 745-750.

Lee, D.C., Halliday, A.N., Fitton, G.J., Poli, G., 1994. Isotopic variations with distance and time in the volcanic islands of the Cameroon Line: evidence of the mantle plume origin. Earth and Planetary Science Letters 123, 119-138.

Lee D. C., Halliday, A. N., Davies, G. R., Essene, E. J., Fitton. J. G., Temdjim, R., 1996. Melt enrichment of shallow depleted mantle: a detailed petrological, trace element and isotopic study of Mantle-derived xenoliths and megacrysts from the Cameroon line. Journal of Petrology 37, 415-441.

Lundstrom, C.C., Hoernle, K., Gill, J., 2003. U-series disequilibria in volcanic rocks from the Canary Islands: plume versus lithosphere melting. Geochimica et Cosmochimica Acta 67, 4153-4177.

MacDonald, R., Rogers, N.W., Fitton, J.G., Black, S., Smith, M., 2001. Plume-lithosphere interactions in the generation of the basalts of the Kenya Rift, East Africa. Journal of Petrology 42, 877-900.

Mahood, G.A., Drake, R.E., 1982. K-Ar dating young rhyolitic rocks: a case study of the Sierra La Primavera, Jalisco, Mexico. Geological Society of American Bulletin 93, 1232-1241.

Marzoli, A., Renne, P.R., Peccirillo, E.M., Castorina, F., Bellieni, G., Melfi, A.G., Nyobe, J.B., N'ni, J.,1999. Silicic magmas from the continental Cameroon Volcanic Line (Oku, Bambouto and Ngaoundere): ${ }^{40} \mathrm{Ar}-{ }^{39} \mathrm{Ar}$ dates, petrology, $\mathrm{Sr}-\mathrm{Nd}-\mathrm{O}$ isotopes and their petrogenetic significance. Contributions to Mineralogy and Petrology 135, 133-150.

Marzoli, A., Peccirillo, E.M., Renne, P.R., Bellieni, G., Iacumin, M., Nyobe, J.B., Tongwa, A.T., 2000. The Cameroon Volcanic Line revisited: petrogenesis of continental basaltic magmas from lithospheric and asthenospheric mantle sources. Journal of Petrology 41, 87-109.

McDonough, W.F., 2003. Compositional model for the Earth's core. In the Mantle and Core (Eds. R.W. Carlson) vol.2. Treatise on Geochemistry (Eds. H.D. Holland and K.K. Turekian). Elservier. Perganon, Oxford. pp 547-568.

Middlemost, E.A.K., 1975. The basalt clan. Earth Sciences Review 11, 337-364.

Miyashiro, A., 1978. Nature of alkalic volcanic rock series. Contribution of Mineralogy and Petrology 66, 91-104.

Morimoto, N., Fabries, J., Ferguson, A.K., Ginzburg, I.V., Ross, M., Seifert, F.A., Zussmann, J., Aoki, K., Gottardi, G., 1988. Nomenclature of pyroxenes. American Mineralogist 173, 1123-1133. 
Ngounouno, I., Déruelle, B., Demaiffe, D., Montigny, R., 2003. Petrology of the Cenozoïc volcanism in the Upper Benue valley, northern Cameroon (Central Africa). Contribution to Mineralogy and Petrology 145, 87-106.

Nkouandou, O.F., Ngounouno, I., Déruelle, B., Ohnenstetter, D., Montigny, R., Demaiffe. D., 2008. Petrology of the Mio-Pliocene volcanism to the North and East of Ngaoundéré (Adamawa, Cameroon). Comptes Rendus Géoscience 340, 28-37.

Nkouathio, D.G., Kagou Dongmo, A., Bardintzeff, J.-M., Wandji, P., Bellon, H., Pouclet, A., 2008. Evolution of volcanism in graben and horst structures along the Cenozoic Cameroon Line (Africa): implications for tectonic evolution and mantle source composition. Mineralogy and Petrology 94, 287-303.

Nzolang, C., 2005. Crustal evolution of the Preacambrian basement in west Cameroon: inference from geochemistry, $\mathrm{Sr}-\mathrm{Nd}$ and experimental investigation of some granitoids and metamorphic rocks. Ph.D. Thesis. Graduate School of Science and Technology, Niigata University, Japan, 207p.

Nzolang, C., Kagami, H., Nzenti, J.P., Holtz, F., 2003. Geochemistry and preliminary data on the Neoproterozoic granitoids from the Bantoun area, West Cameroon: evidence for a derivation from a Paleoproterozoic to Archean crust. Polar Geoscience 16, 196-226.

Rankenburg, K., Lassiter, J.C., Brey, G., 2005. The role of the continental crust and lithospheric mantle in the genesis of Cameroon volcanic line lavas: constraints from isotopic variations in lavas and megacrysts from the Biu and Jos Plateaux. Journal of Petrology 46, 169-190.

Schweitzer, E.L., Papike, J.J., Bence, A.E., 1979. Statistical analysis of clinopyroxenes from deep-sea basalts. American Mineralogist 64, 501-513.

Sibuet, J.-C., Mascle, J., 1978. Plate kinetic implications of Atlantic equatorial fracture zone trends. Geophysic Research 89, 3401-3421.

Smith, J.V., Brown, W.L., 1988. Feldspar Minerals: Second Revised and Extended Edition. Springer Verlag, Berlin Heidelberg, New York, London, Paris, Tokyo.

Steiger, R.H., Jäger, E., 1977. Subcommission on geochronology: convention on the use of decay constants in geo- and cosmochronology. Earth and Planetary Science Letter 36, 359-362.

Stormer, Jr., C. 1983. The effects of recalculation on estimates of temperature and oxygen fugacity from analyses of multicomponent iron-titanium oxides. American Mineralogist 68, 586-594.

Stracke, A., Hofmann, A.W., Hart, S.R. 2005. FOZO, HIMU, and the rest of the mantle zoo. Geochemisty Geophysics Geosystems 6, doi: 10.1029/2004GC000824.

Sun, S., McDonough, W., 1989. Chemical and isotopic systematics of oceanic basalts: implications for mantle composition and processes. Geological Society of London Special Publications 42, 313-345.

Temdjim, R., Boivin, P., Chazot, G., Robin, C.,. Rouleau, E., 2004. L'hétérogénéité du manteau supérieur à l'aplomb du volcan de Nyos (Cameroun) révélée par les enclaves ultrabasiques. Comptes Rendus Géoscience 336, 1239-1244.

Tian, W., Campbell, I.H., Allen, C.M., Guan, P., Pan, W., Chen, M., Yu, H., Zhu, W., 2010. The Tarim picrite - basalt - rhyolite suite, a Permian flood basalt from northwest China with contrasting 
rhyolites produced by fractional crystallization and anatexis. Contributions to Mineralogy and Petrology 160, $407-425$.

Toteu, S.F., Van Schmus, W.R., Penaye, J., Michard, A., 2001. New U-Pb and Sm-Nd data from north-central Cameroon and its bearing on the pre-Pan African history of central Africa. Precambrian Research 108, 45-73.

Tuttle, O.F., Bowen, N.L., 1958. Origin of granite in the light of experimental studies in the system $\mathrm{NaAlSi}_{3} \mathrm{O}_{8}-\mathrm{KAlSi}_{3} \mathrm{O}_{8}-\mathrm{SiO}_{2}-\mathrm{H} 2 \mathrm{O}$. Geological Society of America Memoir, 74.

Wang, K., Plank, T., Walker, J.D., Smith, E.I., 2002. A mantle melting profile across the Basin and Range, SW USA. Journal of Geophysical Research 107, 10.1029/2001JB000209.

Weaver, B.L., 1991. The origin of ocean island basalt end-member compositions: trace element and isotopic constraints. Earth and Planetary Science Letters 104, 381-397.

Yokoyama, T., Aka, F.T., Kusakabe, M., Nakamura, E., 2007. Plume-lithosphere interaction beneath Mt. Cameroon volcano, west Africa: constraints from ${ }^{238} \mathrm{U}_{-}{ }^{230} \mathrm{Th}-{ }^{226} \mathrm{Ra}$ and $\mathrm{Sr}-\mathrm{Nd}-\mathrm{Pb}$ isotope systematics. Geochimica et Cosmochimica Acta 71, 1835-1854.

Zimmermann, J.-L., Vernet, M., Guyetand, G., Dautel, D., 1985. Données sur potassium et argon (de 1976 à 1984) dans quelques échantillons géochimiques de référence, Geostandards Newsletter 9, 205208.

Zindler, A., Hart, S.R., 1986. Chemical geodynamics. Annual Review of Earth and Planetary Sciences $14,493-571$.

\section{Figure captions}

Fig. 1. (a) Location of Cameroon in Africa; (b) location of the Bamenda Mountains along the Cameroon line showing the location (black) of the Cameroon line volcanic rocks (adapted after Halliday et al. (1988)); the boundary between continental and oceanic crust is taken from Emery and Uchupi (1984) and oceanic transform faults are from Sibuet and Mascle (1978); (c) Simplified geological map of the Bamenda area. $\mathrm{C}=$ Cameroon; $\mathrm{COA}=$ West African craton; $\mathrm{CC}=$ Congo craton; $\mathrm{CT}=$ Tanzanian craton; $\mathrm{CK}=$ Kalahari craton. African cratons are after Kampunzu and Popoff (1991).

Fig. 2. Total alkali vs. silica (TAS) classification diagram for Bamenda mafic lavas (Le Bas et al.,1986). Inset: $\mathrm{Na}_{2} \mathrm{O}$ vs. $\mathrm{K}_{2} \mathrm{O}$ subdivision diagram of the alkaline series (Middlemost, 1975). The alkaline - subalkaline dividing line is from Miyashiro (1978).

Fig. 3. a) End-member compositional variation in clinopyroxene (classification after Morimoto et al., 1988) and olivine from Bamenda mafic lavas. b) An-Ab-Or triangular plot (Smith and Brown, 1988) showing the composition of plagioclase from Bamenda mafic lavas. Symbols are as follows: triangles $=$ basanite; rectangles $=$ basalt; circles $=$ hawaiite $;$ inverted triangles $=$ mugearite .

Fig. 4. Major-element variations (in wt. \%) along rim to core traverses across one green-core clinopyroxene phenocryst (a) (sample BA37), two typical diopsides (b) and (c) (samples BA37 and BA61), and one plagioclase phenocryst (d) (Sample BA26).

Fig. 5. Variation of major element oxides (in wt. \%) in the Bamenda mafic lavas as a function of Mg\#. 
Fig. 6. Variation of selected trace elements (in ppm) versus $\mathrm{SiO}_{2}$ (in wt. \%) or $\mathrm{Mg \#}$ for Bamenda mafic lavas.

Fig. 7. Chondrite normalized rare earth element patterns of Bamenda mafic lavas a): basanite, b): basalt, c): hawaiite, d): mugearite. Values of chondrite are from McDonough (2003). Also plotted are patterns of OIB, N-MORB and E-MORB from Sun and McDonough (1989).

Fig. 8. Primitive mantle-normalized multi-element patterns for the Bamenda mafic lavas. a): basanite, b): basalt, c): hawaiite, d): mugearite. Patterns for OIB, E-MORB and N-MORB are given for comparison. The normalization values are from McDonough (2003) and values of OIB, N-MORB and E-MORB from Sun and McDonough (1989).

Fig. ${ }^{9}{ }^{87} \mathrm{Sr} /{ }^{86} \mathrm{Sr}$ vs. ${ }^{143} \mathrm{Nd} /{ }^{144} \mathrm{Nd}$ (a); ${ }^{206} \mathrm{~Pb} /{ }^{204} \mathrm{~Pb}$ vs. ${ }^{87} \mathrm{Sr} /{ }^{86} \mathrm{Sr}$ (b); ${ }^{143} \mathrm{Nd} /{ }^{144} \mathrm{Nd}$ vs. ${ }^{206} \mathrm{~Pb} /{ }^{204} \mathrm{~Pb}$ (c); ${ }^{20} \mathrm{~Pb} /{ }^{204} \mathrm{~Pb}$ vs. ${ }^{207} \mathrm{~Pb} /{ }^{204} \mathrm{~Pb}$ (d) diagrams for Bamenda mafic rocks. The fields of HIMU, OIB, FOZO, Dupal OIB, EMI and EM2 are from Hamelin and Allègre (1985), Zindler and Hart (1986), Hart (1984, 1988), Hart et al. (1992), Hawkesworth et al. (1984), Weaver (1991). Low Nd (LoNd) array and northern Hemisphere Reference Line (NHRL) are from Hart (1984). The fields for Atlantic-Pacific MORB are from Hamelin and Allègre (1985) and references therein. Literature data for CVL are compiled from Halliday et al. (1988, 1990), Lee et al. (1994), Marzoli et al. (1999, 2000), Rankenburg et al. (2005), Yokoyama et al. (2007); Nkouandou et al. (2008) Nkouathio et al. (2008).

Fig. 10. ${ }^{87} \mathrm{Sr} /{ }^{86} \mathrm{Sr}$ and $\mathrm{La} / \mathrm{Nb}$ variations vs. $\mathrm{MgO}$ contents of the Bamenda mafic rocks.

Fig. 11. Present-day ${ }^{87} \mathrm{Sr} /{ }^{86} \mathrm{Sr}$ vs. age of the mafic samples from Bamenda. Symbols as in figure 10.

Fig. 12. Zr vs. Th for mafic lavas of Bamenda Mountains.

Fig. 13. Trace element composition of some Bamenda basalts with $\mathrm{Sr}$ and Eu positive anomalies compared to the composition of pargasites from amphibole-bearing spinel lherzolites from the Nyos locality (Temdjim et al., 2004) and pyroxenites from Youkou (France et al., submitted). 


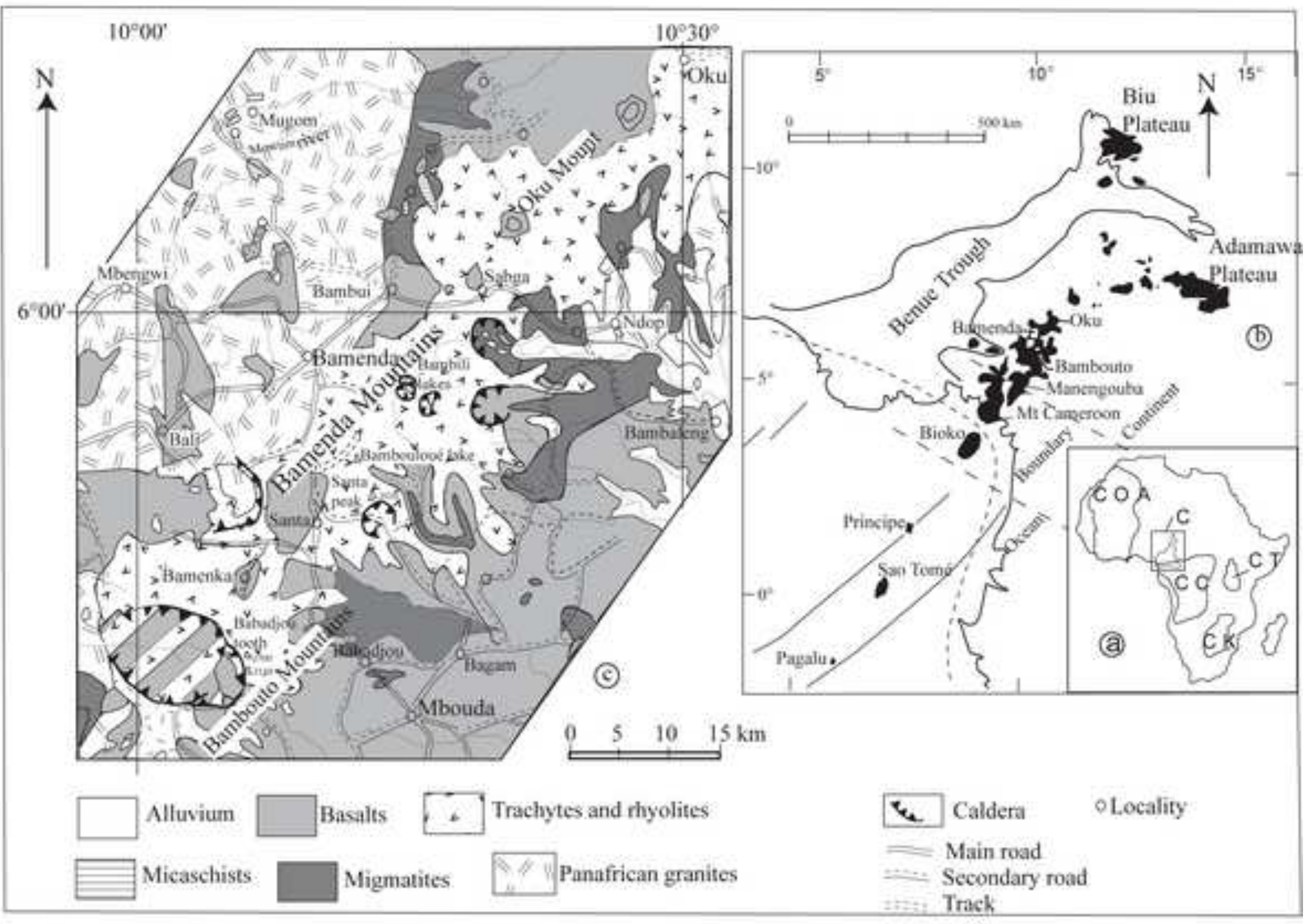

Fig. 1 
Click here to download high resolution image

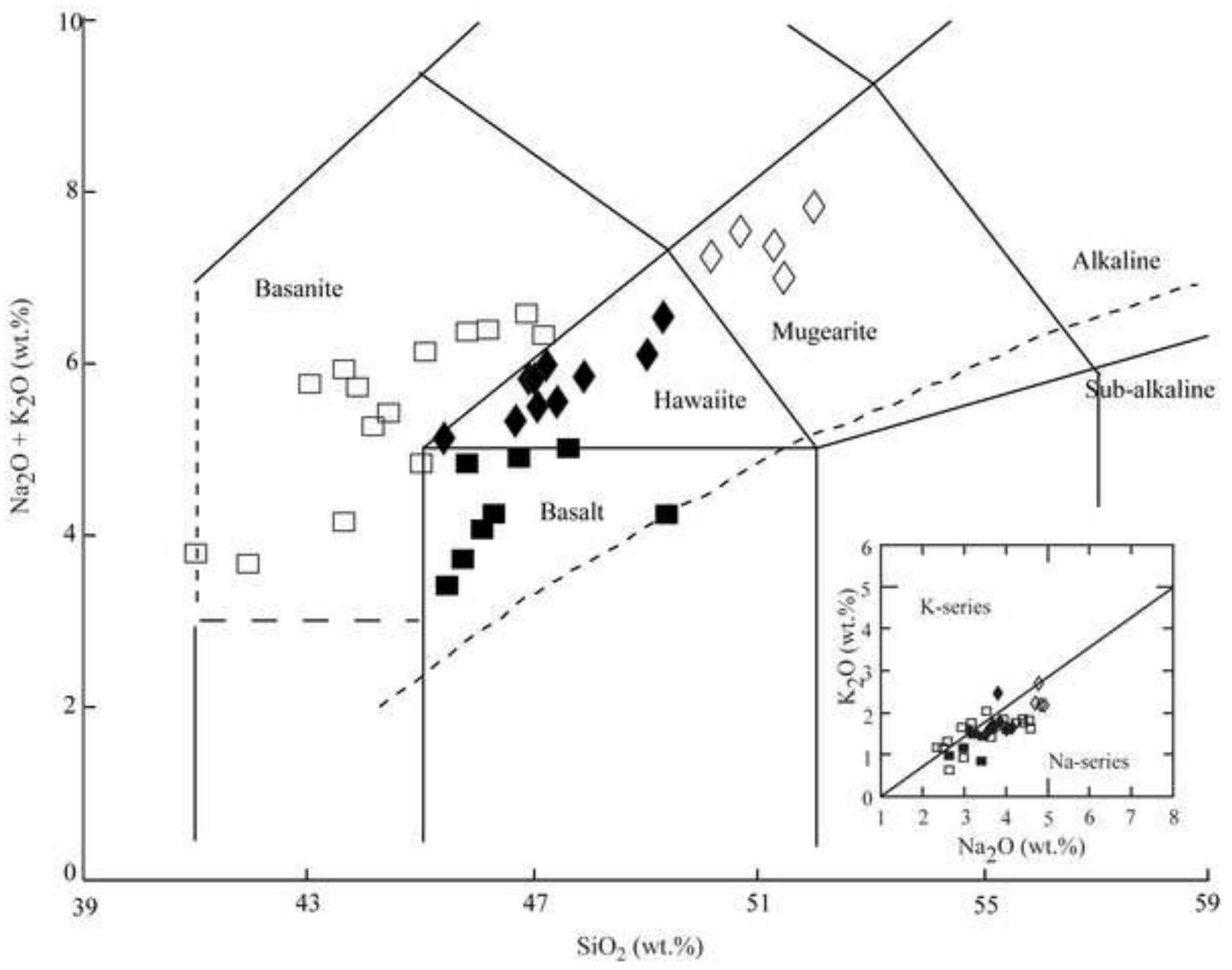

Fig. 2 


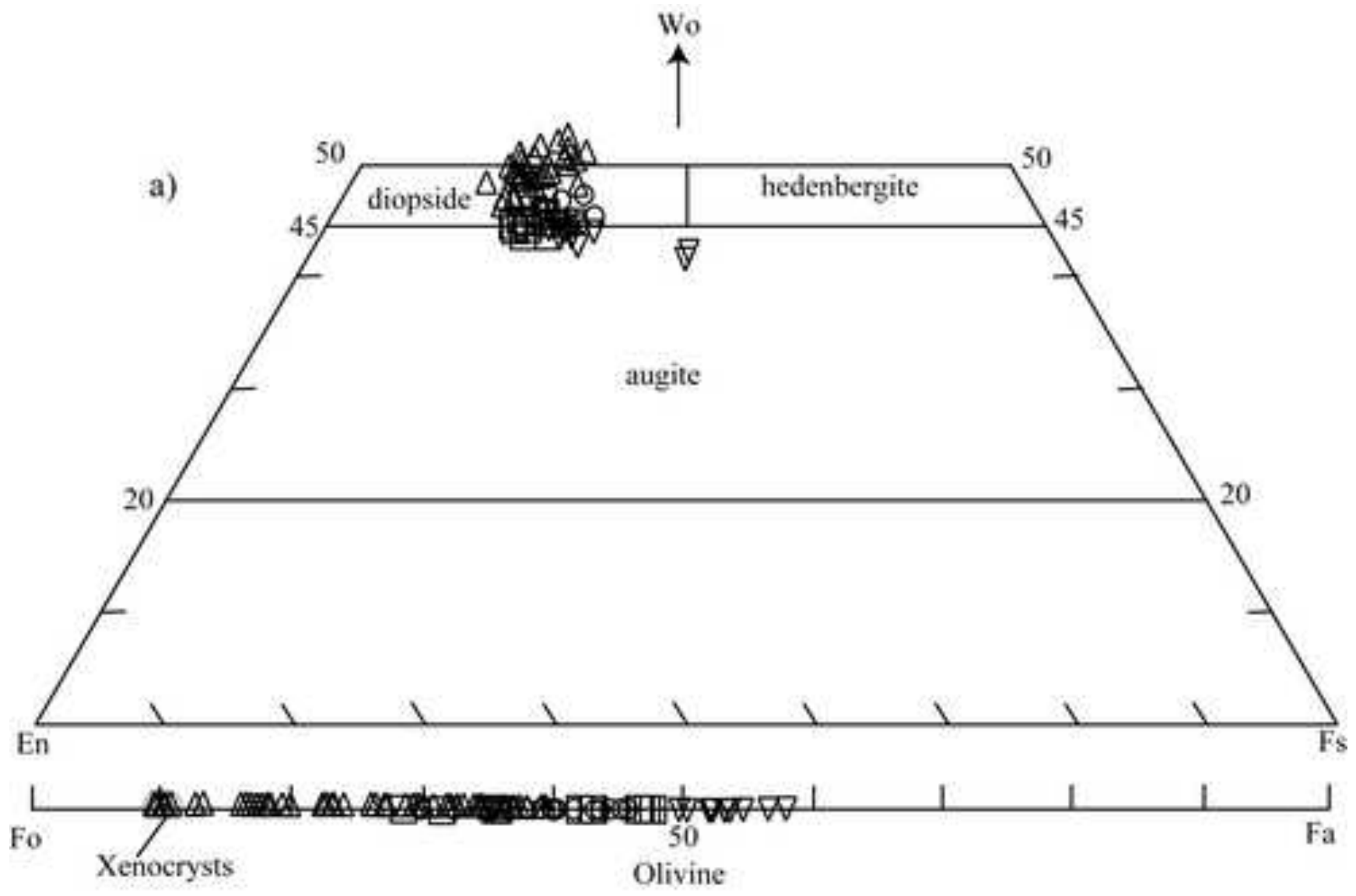

b)

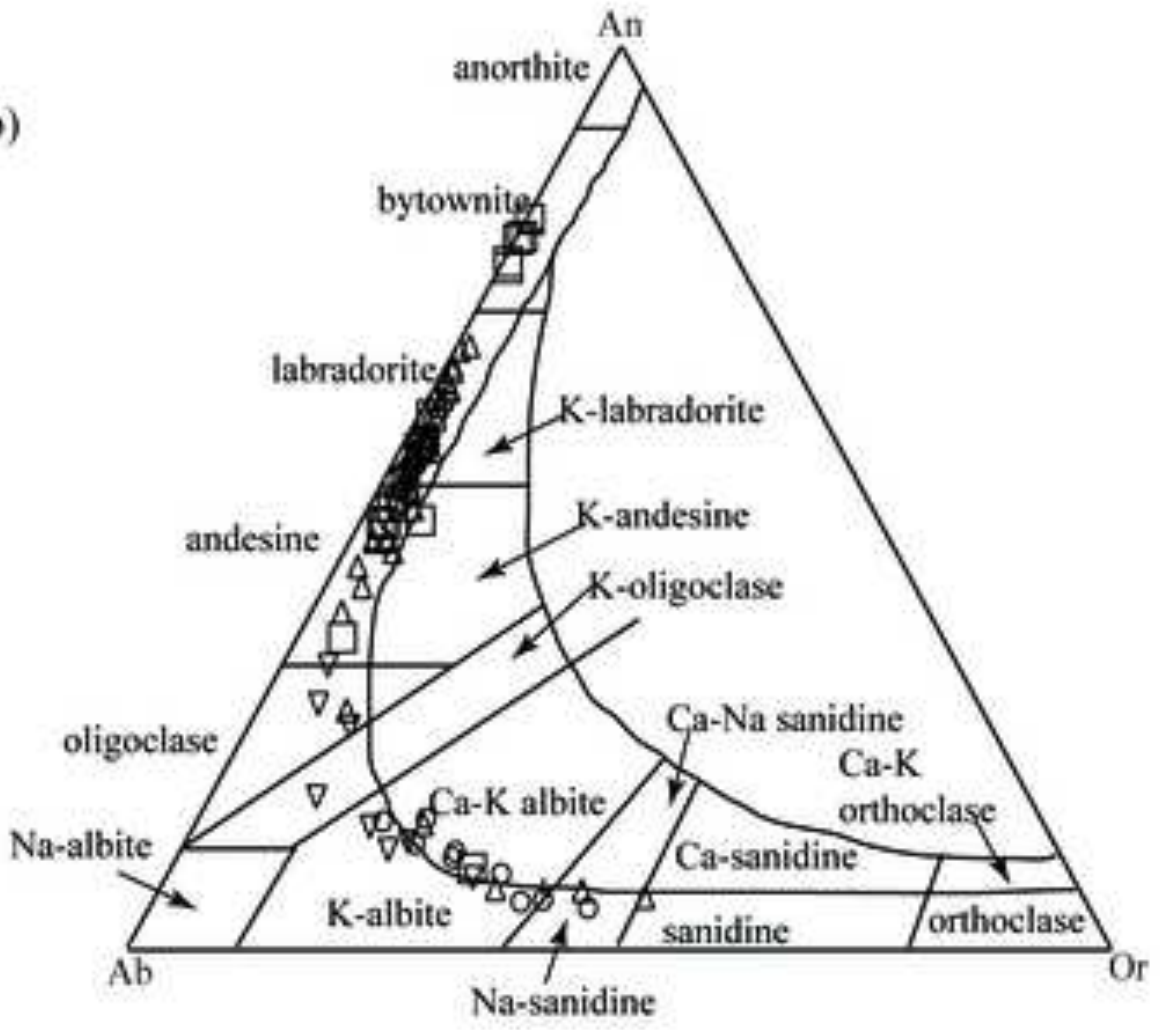

Fig. 3 


\section{Figure}

Click here to download high resolution image
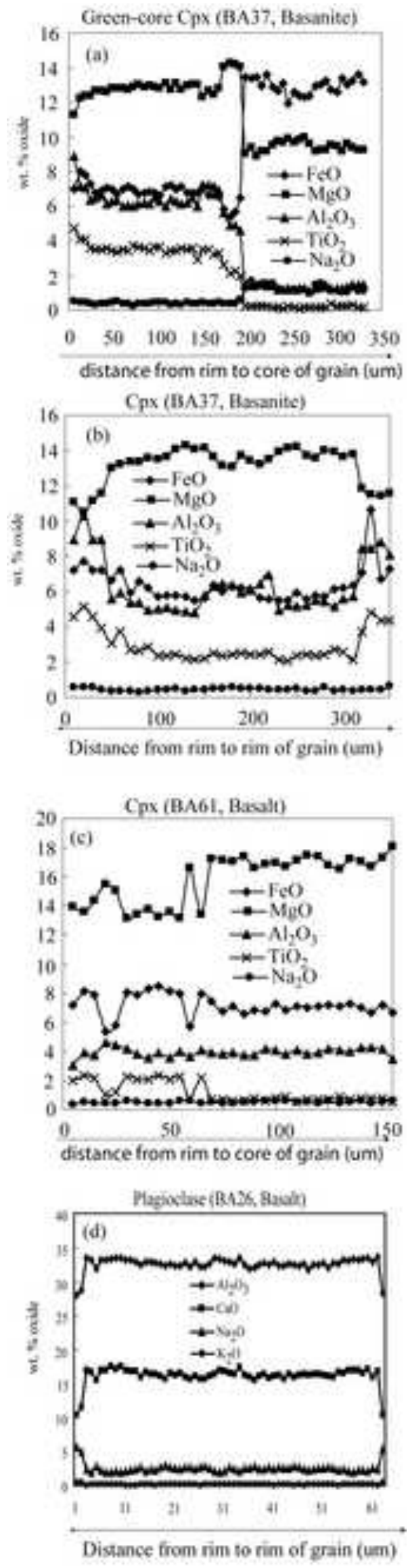

Fig. 4 

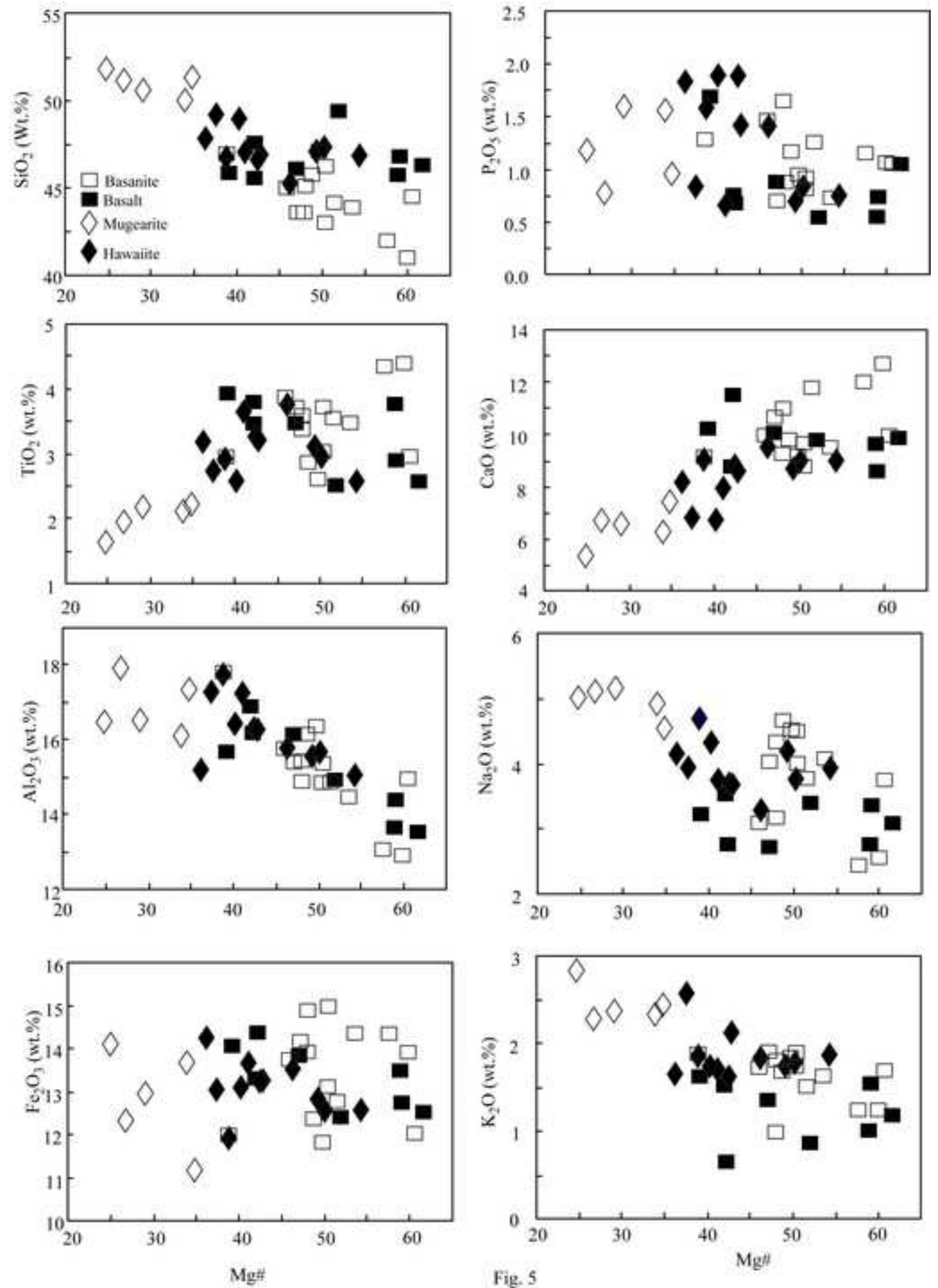

Fig. 5 

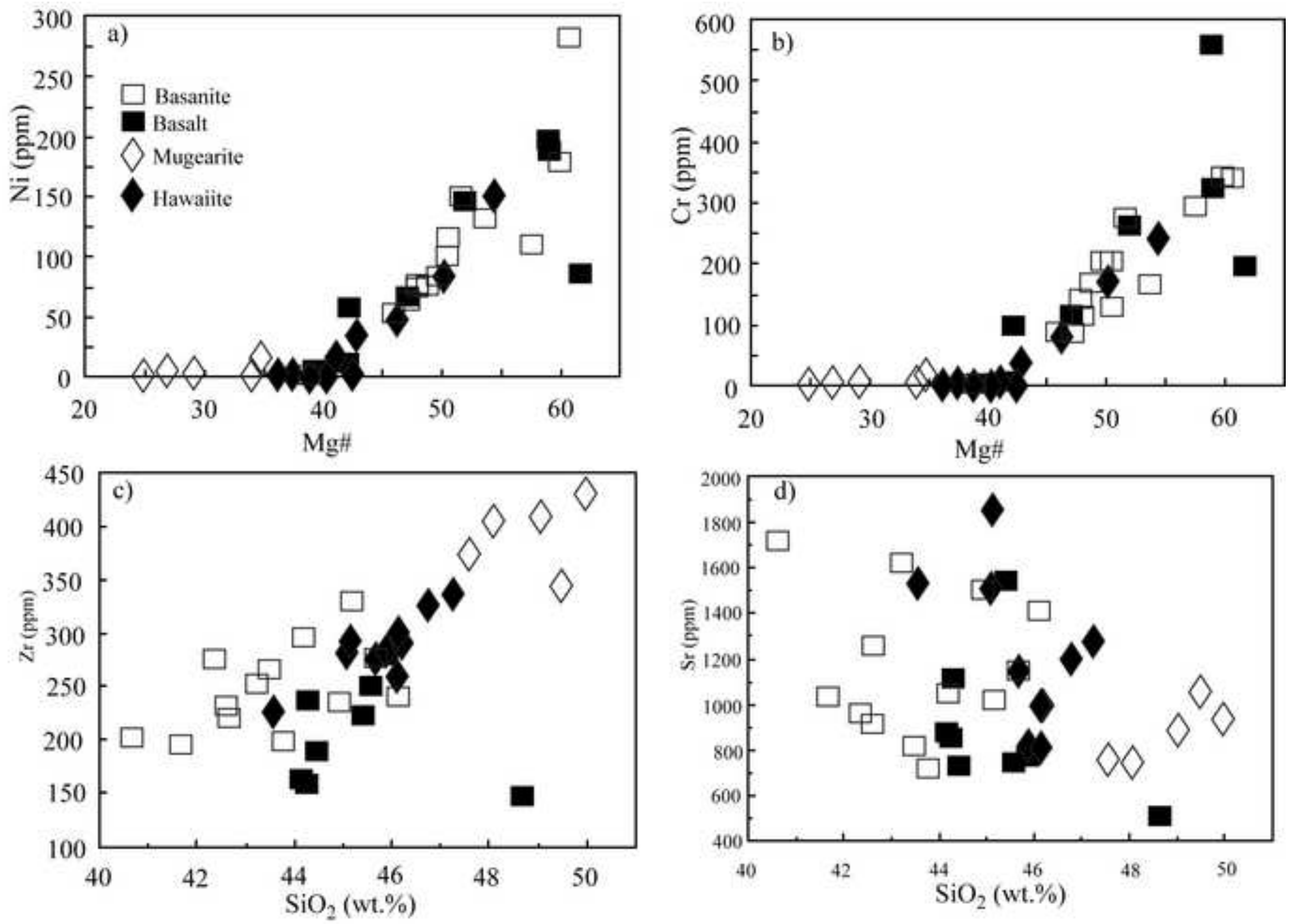

Fig. 6 
Click here to download high resolution image
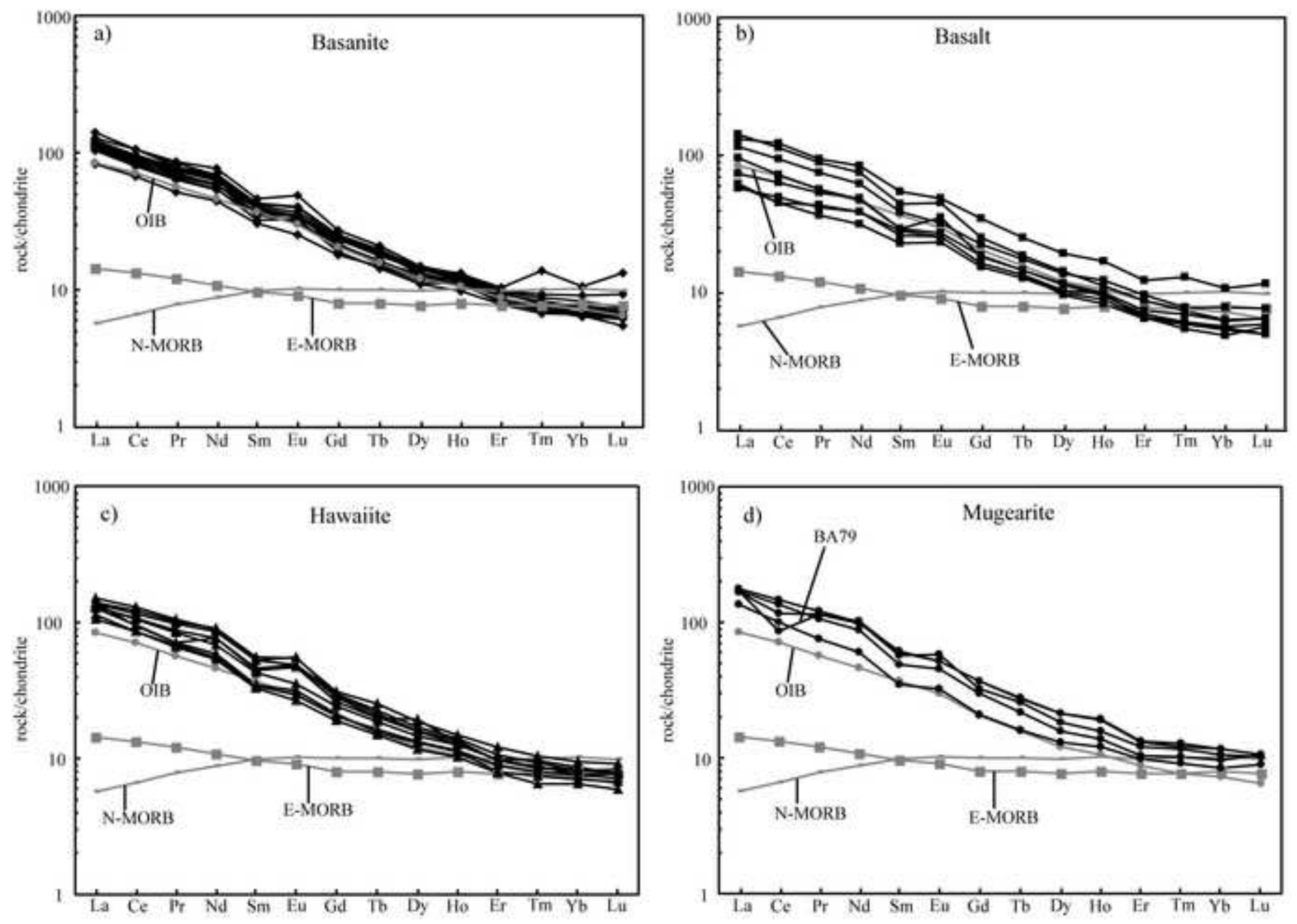

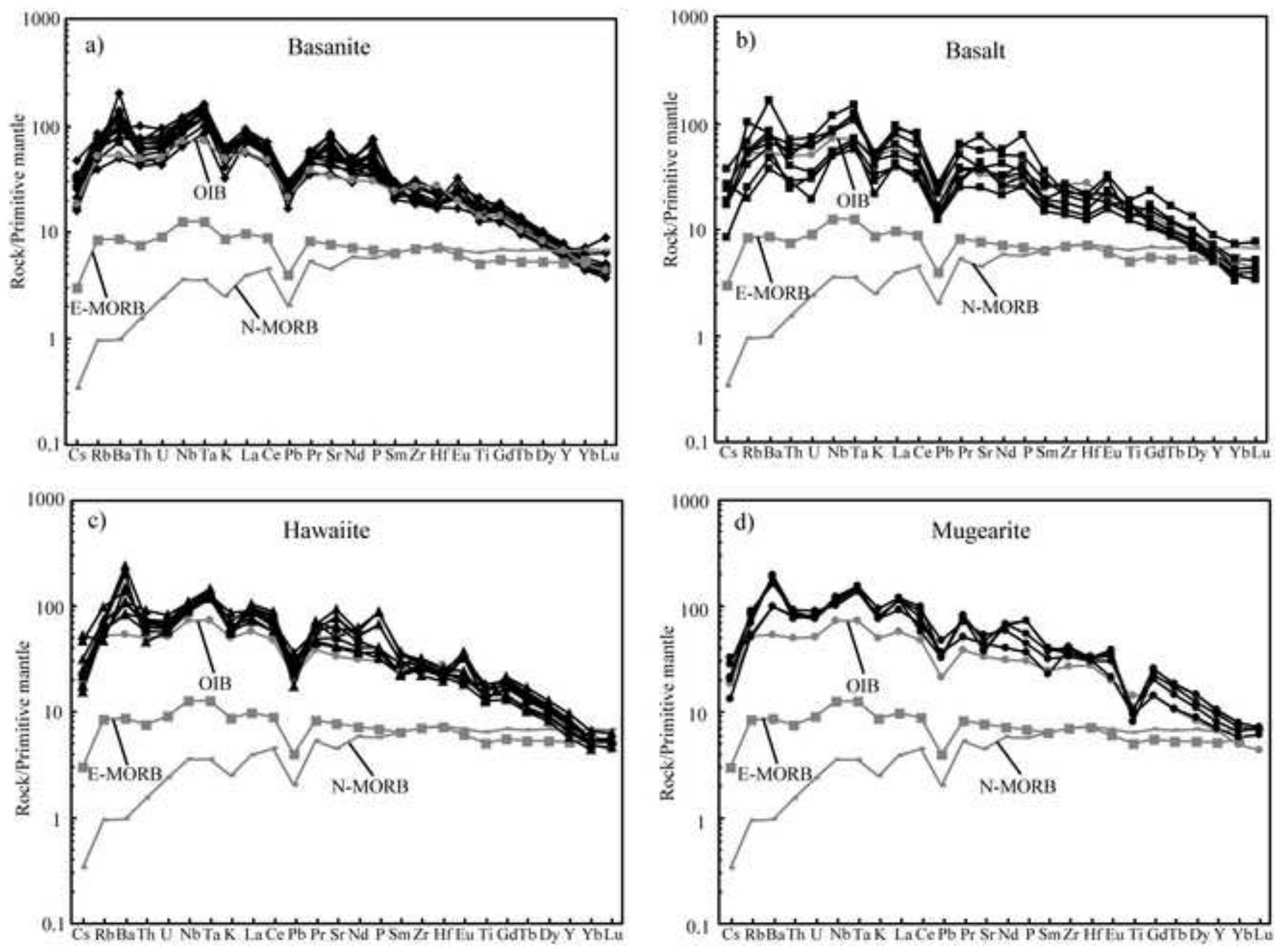

Fig. 8 

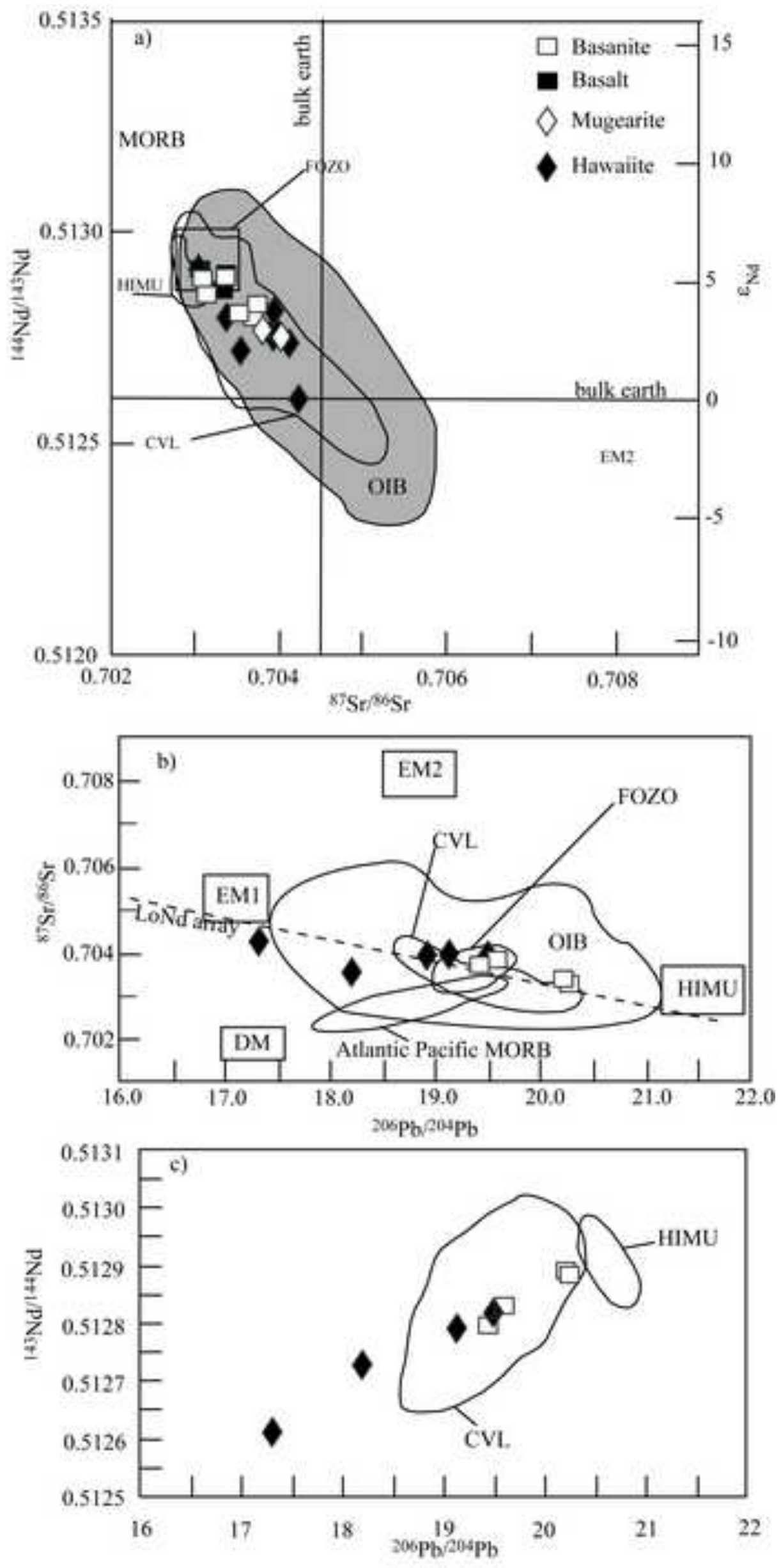

Fig. 9 


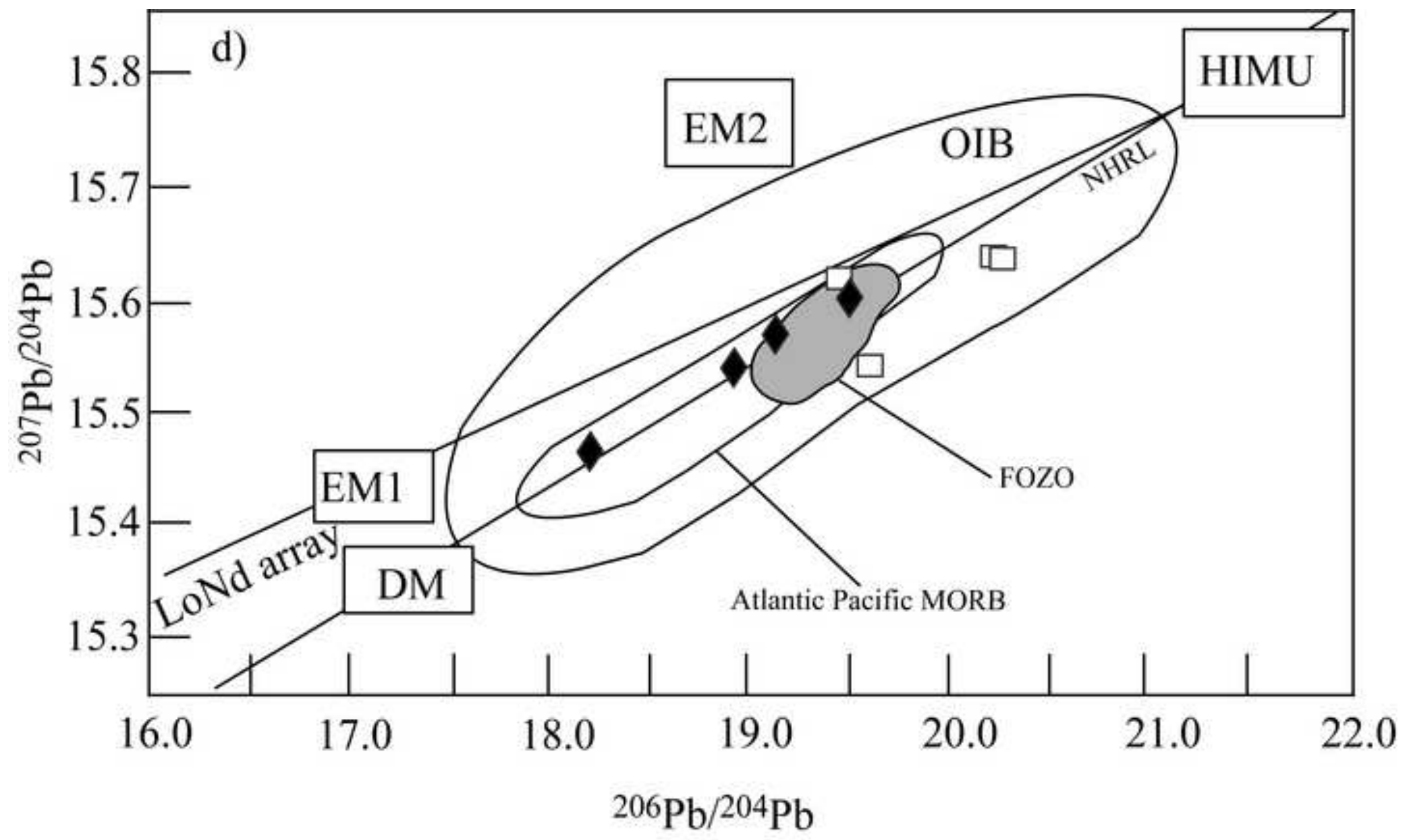

Fig. 9 (continued) 


\section{Figure}

Click here to download high resolution image

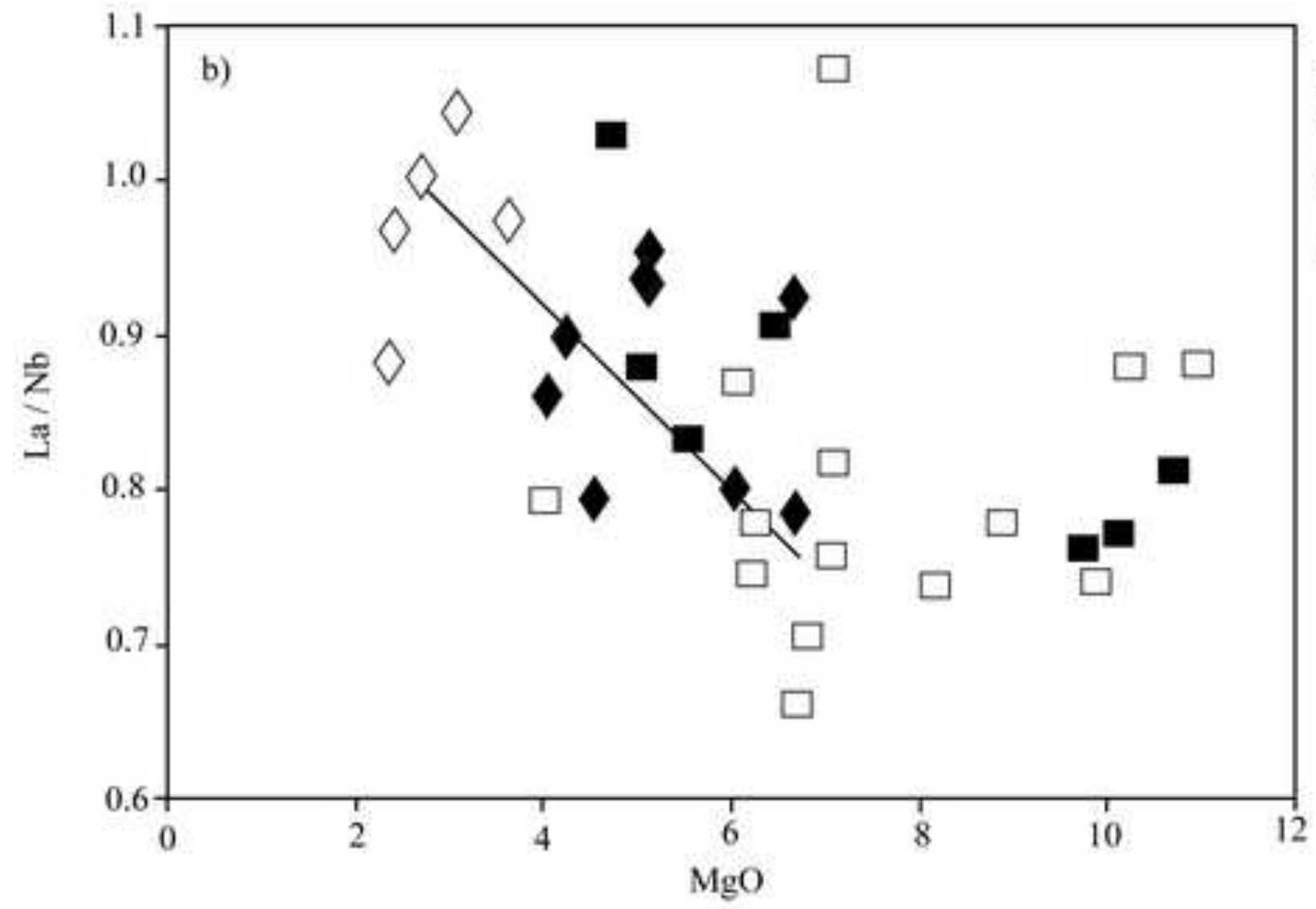

Basanite

Basalt

$\diamond$ Mugearite

- Hawaiite

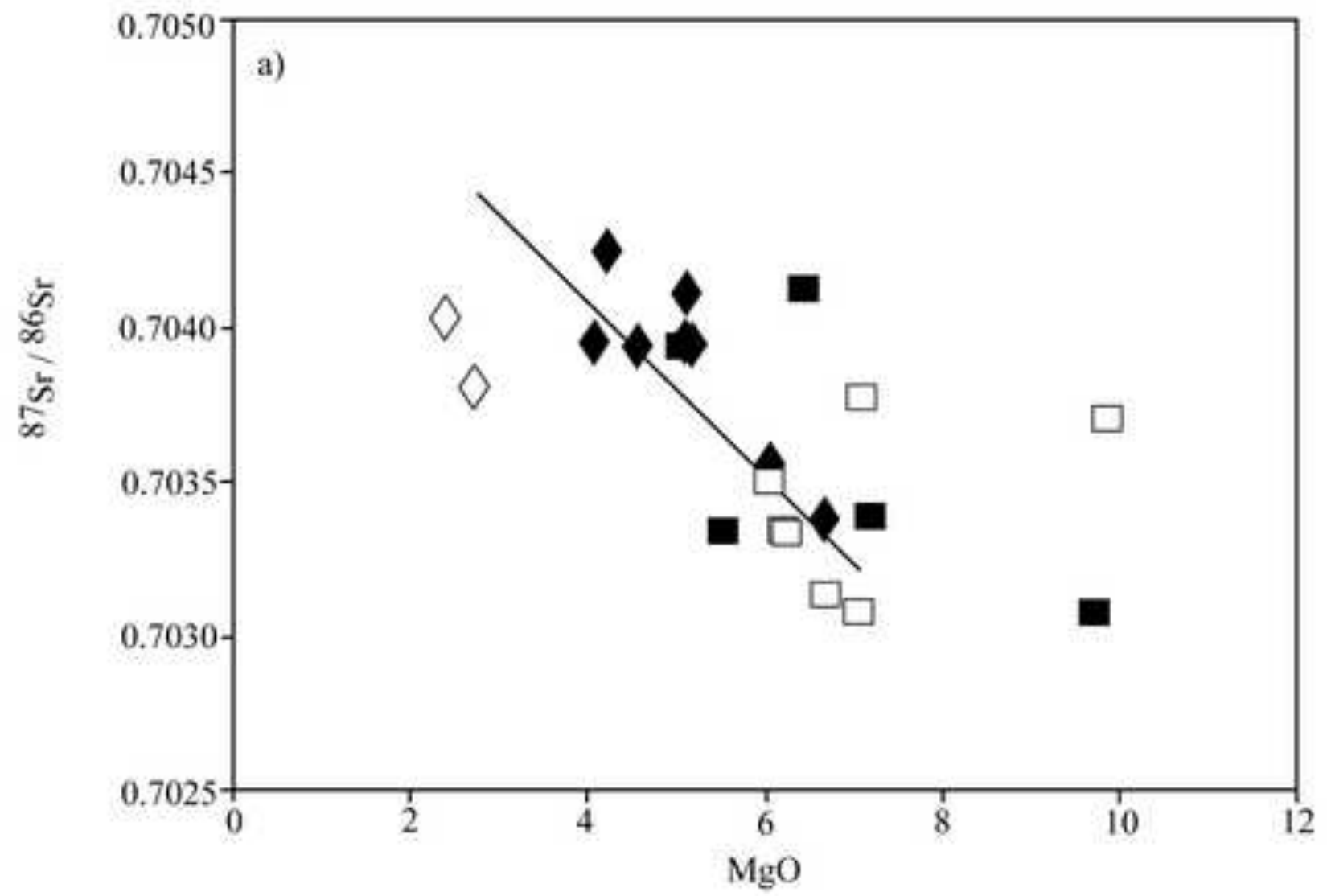

Fig. 10 
Click here to download high resolution image

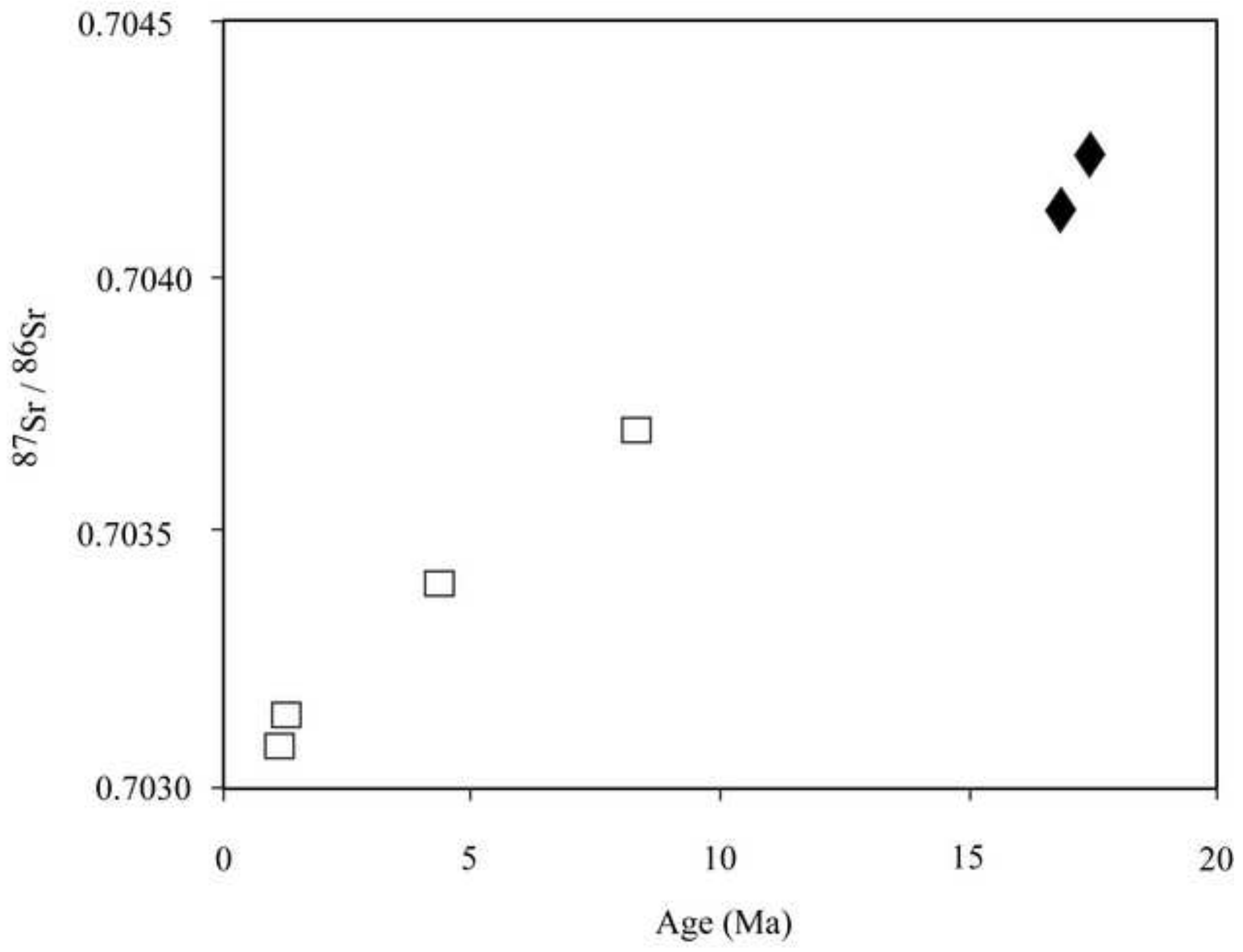

Fig. 11 


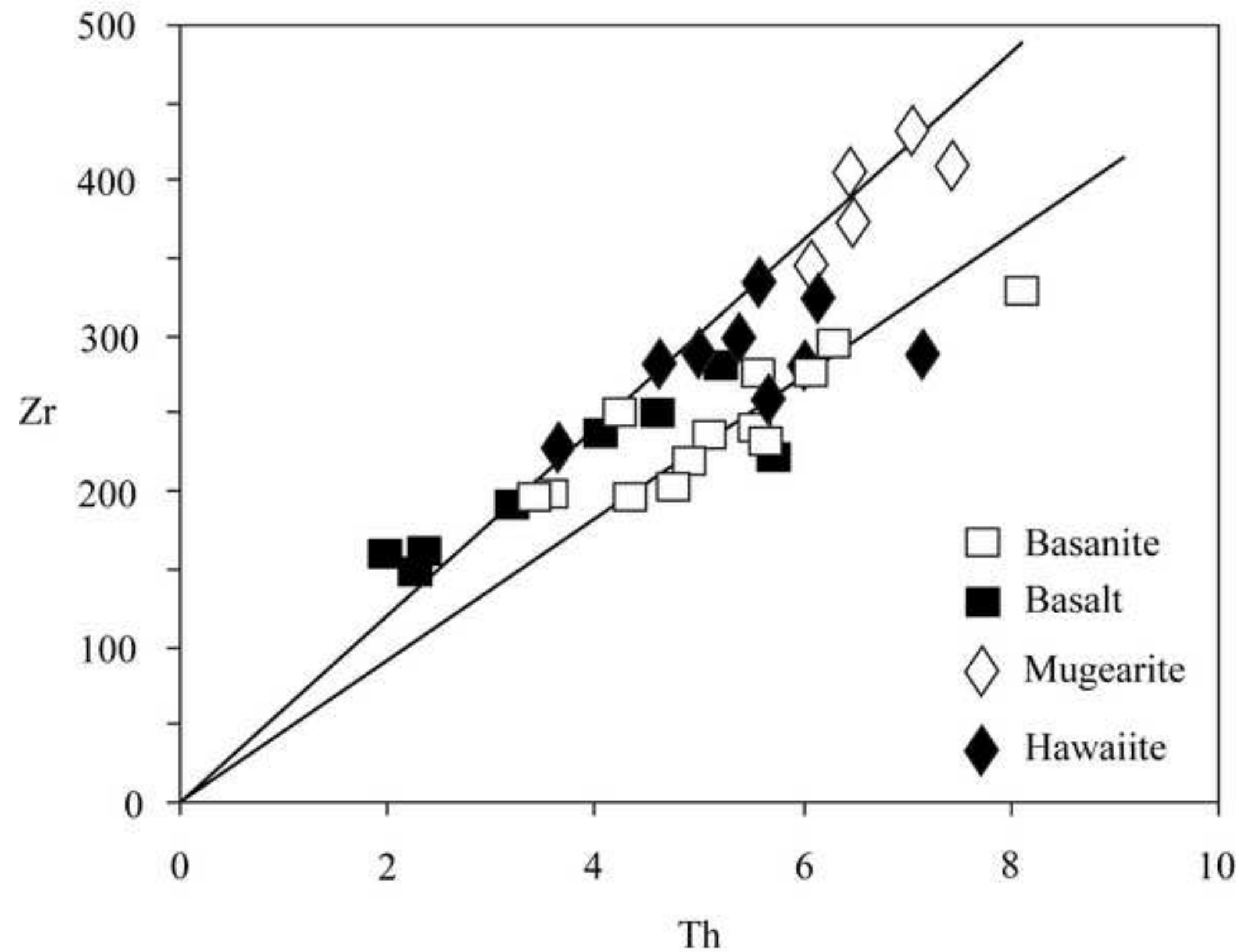

Fig. 12 


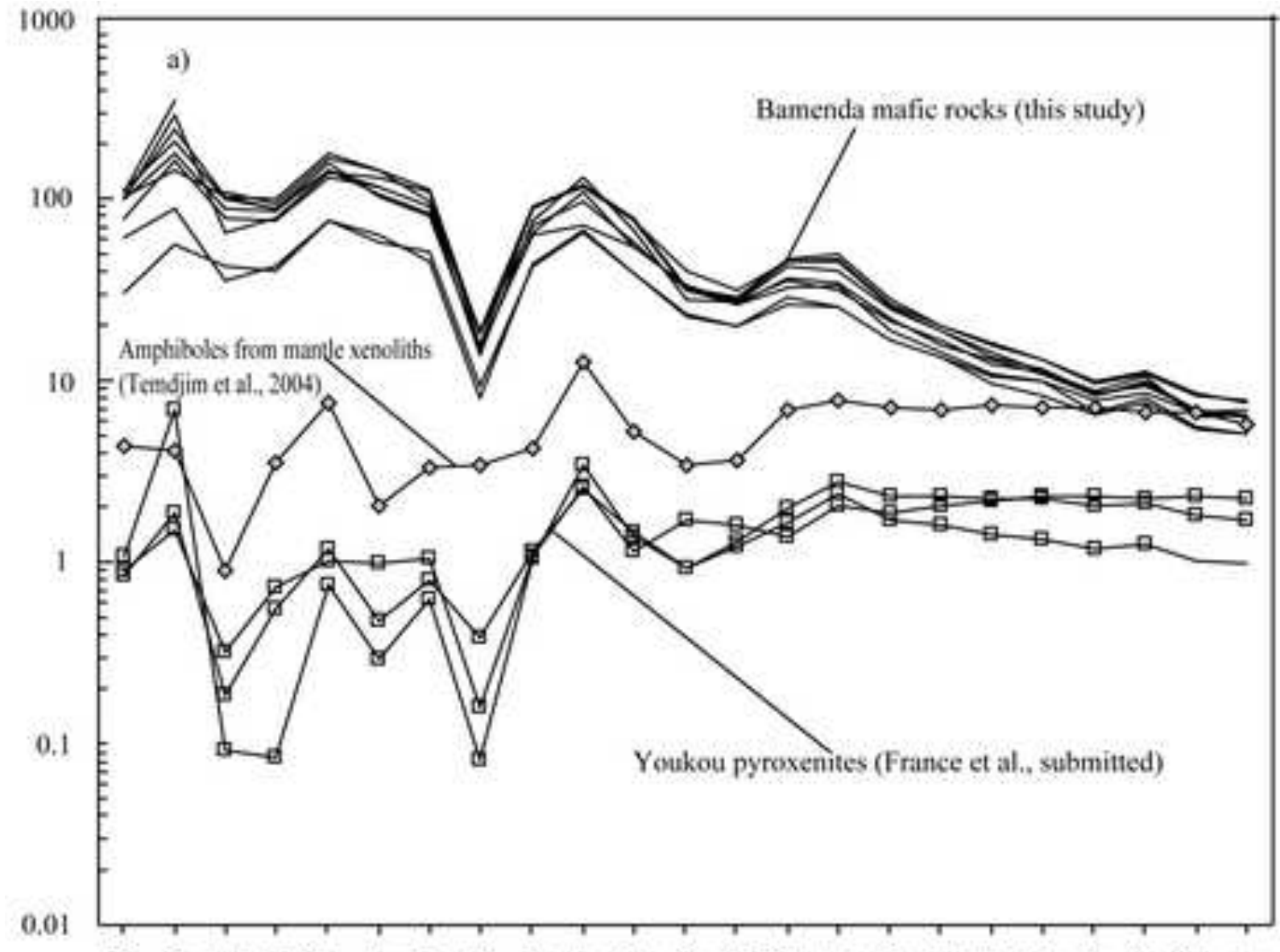

$\mathrm{Rb} \mathrm{Ba}$ Th U Nb La Ce Pb Pr Sr Nd Zr Hr Sm Eu Gd Tb Dy Ho Er Y Yb Lu

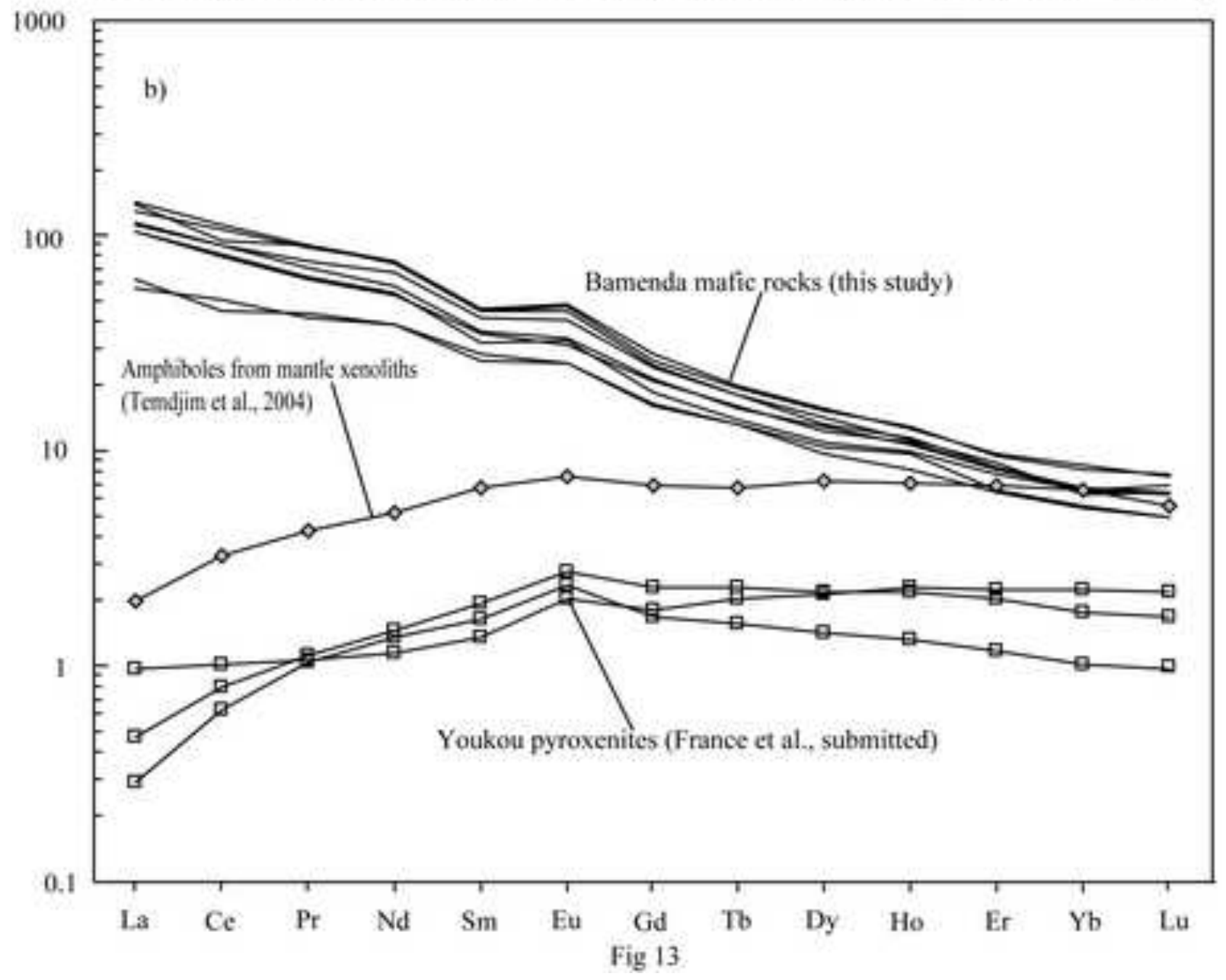


Table1. Main mineralogical features for the different rock types.

\begin{tabular}{lcccc}
\hline & Basanite & Basalt & Hawaiite & Mugearite \\
\hline Olivine (Fo) & $62-87$ & $52-85$ & $54-70$ & $42-50$ \\
Ca-rich Cpx & & & & \\
Wo & $46-52$ & $44-46$ & $44-47$ & $41-45$ \\
En & $34-41$ & $38-41$ & $34-39$ & $29-38$ \\
Fs & $11-15$ & $15-16$ & $14-17$ & $17-29$ \\
Mica (X & & - & Phlogopite & - \\
Feldspathoids & - & - & $-70-0.82$ & - \\
Plagioclase (An) & $1-66$ & $9-81$ & $5-61$ & $8-55$ \\
Titanomagnetite (Usp) & $48-86$ & $77-85$ & $76-79$ & $73-77$ \\
Apatite & & & + & + \\
Calcite & & & + & + \\
\hline
\end{tabular}


Table 2. Major and trace element data for representative samples of the Bamenda mafic lavas. Oxides as wt.\%; trace elements in ppm.

\begin{tabular}{|c|c|c|c|c|c|}
\hline Basanite & BA04 & BA31 & BA43 & BA68 & BA81 \\
\hline \multicolumn{6}{|l|}{ wt.\% } \\
\hline $\mathrm{SiO}_{2}$ & 44.17 & 43.47 & 45.65 & 43.75 & 42.36 \\
\hline $\mathrm{TiO}_{2}$ & 3.32 & 3.45 & 2.86 & 2.91 & 3.66 \\
\hline $\mathrm{Al}_{2} \mathrm{O}_{3}$ & 15.14 & 14.33 & 17.31 & 14.71 & 14.64 \\
\hline $\mathrm{Fe}_{2} \mathrm{O}_{3}$ & 13.64 & 14.21 & 11.67 & 11.86 & 14.78 \\
\hline $\mathrm{MnO}$ & 0.2 & 0.2 & 0.2 & 0.2 & 0.17 \\
\hline $\mathrm{MgO}$ & 6.8 & 8.86 & 4.01 & 9.85 & 8.14 \\
\hline $\mathrm{CaO}$ & 9.05 & 9.38 & 8.88 & 9.83 & 9.54 \\
\hline $\mathrm{Na}_{2} \mathrm{O}$ & 4.25 & 4.04 & 4.59 & 3.69 & 3.95 \\
\hline $\mathrm{K}_{2} \mathrm{O}$ & 1.77 & 1.62 & 1.82 & 1.66 & 1.72 \\
\hline $\mathrm{P}_{2} \mathrm{O} 5$ & 0.86 & 0.72 & 1.55 & 1.04 & 0.91 \\
\hline LOI & 0.41 & -0.2 & 1.04 & 0.33 & 0.2 \\
\hline Total & 99.61 & 100.08 & 99.58 & 99.83 & 100.07 \\
\hline $\mathrm{Mg} \#$ & 48 & 54 & 39 & 61 & 50 \\
\hline \multicolumn{6}{|l|}{ ppm } \\
\hline $\mathrm{Nb}$ & 76.5 & 63.5 & 77.8 & 49.6 & 70.4 \\
\hline $\mathrm{Zr}$ & 296 & 266 & 277 & 199 & 276 \\
\hline $\mathrm{Y}$ & 32.5 & 28.7 & 32.5 & 26.6 & 29.4 \\
\hline $\mathrm{Sr}$ & 1050 & 819 & 1154 & 718 & 958 \\
\hline $\mathrm{Rb}$ & 46.5 & 39.6 & 42.8 & 28.9 & 37.0 \\
\hline $\mathrm{Ga}$ & 25.1 & 21.9 & 6.5 & 22.4 & 21.5 \\
\hline $\mathrm{Ni}$ & 76.6 & 131 & 2.2 & 283 & 100 \\
\hline Co & 40 & 46.6 & 19.6 & 56 & 46.9 \\
\hline $\mathrm{Cr}$ & 115 & 167 & 1.6 & 339 & 131 \\
\hline $\mathrm{Sc}$ & 20.2 & 22.8 & 13.9 & 1.0 & 17.6 \\
\hline V & 227 & 230 & 134 & 219 & 248 \\
\hline Cs & 0.99 & 0.7 & 0.5 & 0.5 & 0.4 \\
\hline $\mathrm{Ba}$ & 599 & 511 & 587 & 472 & 516 \\
\hline $\mathrm{La}$ & 53.9 & 49.2 & 61.6 & 36.6 & 51.9 \\
\hline $\mathrm{Ce}$ & 109.7 & 98.9 & 122.3 & 75.3 & 107.2 \\
\hline $\operatorname{Pr}$ & 12.7 & 11.5 & 14.3 & 8.8 & 12.5 \\
\hline $\mathrm{Nd}$ & 52.8 & 48.7 & 57.7 & 37.3 & 54.3 \\
\hline $\mathrm{Sm}$ & 10.4 & 10.7 & 11.1 & 8.3 & 10.8 \\
\hline $\mathrm{Eu}$ & 3.4 & 3.5 & 3.7 & 2.5 & 3.4 \\
\hline $\mathrm{Gd}$ & 8.6 & 9.0 & 9.3 & 6.6 & 8.7 \\
\hline $\mathrm{Tb}$ & 1.2 & 1.3 & 1.3 & 1.0 & 1.2 \\
\hline Dy & 6.6 & 6.9 & 6.5 & 5.1 & 6.5 \\
\hline Ho & 1.2 & 1.3 & 1.3 & 1.1 & 1.2 \\
\hline $\mathrm{Er}$ & 2.8 & 3.1 & 2.9 & 2.6 & 2.6 \\
\hline $\mathrm{Tm}$ & 0.4 & 0.6 & 0.4 & 0.4 & 0.4 \\
\hline $\mathrm{Yb}$ & 2.3 & 3.2 & 2.7 & 1.9 & 2.2 \\
\hline $\mathrm{Lu}$ & 0.3 & 0.6 & 0.4 & 0.3 & 0.3 \\
\hline $\mathrm{Hf}$ & 6.4 & 6.9 & 6.3 & 4.9 & 6.4 \\
\hline $\mathrm{Ta}$ & 5.5 & 5.2 & 5.9 & 3.8 & 5.2 \\
\hline $\mathrm{Pb}$ & 3.8 & 4.4 & 3.6 & 3.2 & 3.5 \\
\hline Th & 6.3 & 5.9 & 5.6 & 3.6 & 6.1 \\
\hline $\mathrm{U}$ & 1.6 & 1.9 & 1.5 & 1.0 & 1.5 \\
\hline$\Delta \mathrm{Nb}$ & 0.3 & 0.2 & 0.3 & 0.3 & 0.3 \\
\hline
\end{tabular}




\begin{tabular}{|c|c|c|c|c|c|}
\hline Basalt & BA02 & BA11 & BA61 & BA87 & BA88 \\
\hline \multicolumn{6}{|l|}{ Wt. $\%$} \\
\hline $\mathrm{SiO}_{2}$ & 44.27 & 44.19 & 45.4 & 48.68 & 45.6 \\
\hline $\mathrm{TiO}_{2}$ & 3.65 & 3.68 & 2.52 & 2.47 & 2.82 \\
\hline $\mathrm{Al}_{2} \mathrm{O}_{3}$ & 13.21 & 15.77 & 13.25 & 14.72 & 14.04 \\
\hline $\mathrm{Fe}_{2} \mathrm{O}_{3}$ & 13.06 & 13.95 & 12.3 & 12.21 & 12.44 \\
\hline $\mathrm{MnO}$ & 0.16 & 0.15 & 0.17 & 0.16 & 0.2 \\
\hline $\mathrm{MgO}$ & 10.13 & 5.53 & 10.72 & 7.17 & 9.73 \\
\hline $\mathrm{CaO}$ & 9.33 & 11.14 & 9.64 & 9.58 & 8.37 \\
\hline $\mathrm{Na}_{2} \mathrm{O}$ & 2.65 & 2.68 & 3.02 & 3.34 & 3.27 \\
\hline $\mathrm{K}_{2} \mathrm{O}$ & 0.96 & 0.63 & 1.16 & 0.84 & 1.51 \\
\hline $\mathrm{P}_{2} \mathrm{O}_{5}$ & 0.53 & 0.66 & 1.03 & 0.53 & 0.71 \\
\hline LOI & 1.68 & 1.2 & 0.38 & 0.24 & 1.2 \\
\hline Total & 99.63 & 99.58 & 99.59 & 99.94 & 99.89 \\
\hline $\mathrm{Mg} \#$ & 59 & 42 & 62 & 52 & 59 \\
\hline \multicolumn{6}{|l|}{ ppm } \\
\hline $\mathrm{Nb}$ & 33 & 33.1 & 77.9 & 71.1 & 55.8 \\
\hline $\mathrm{Zr}$ & 159 & 162 & 222 & 147 & 251 \\
\hline Y & 21.6 & 23.2 & 30 & 22.9 & 25.3 \\
\hline $\mathrm{Sr}$ & 851 & 874 & 1540 & 504 & 744 \\
\hline $\mathrm{Rb}$ & 24.8 & 12.0 & 41.0 & 48.9 & 32.3 \\
\hline $\mathrm{Ga}$ & 19.8 & 4.8 & 19.9 & 21.1 & 19.6 \\
\hline $\mathrm{Ni}$ & 196 & 57.5 & 84.4 & 145 & 187 \\
\hline Co & 53.1 & 46.1 & 33.2 & 40.4 & 42.5 \\
\hline $\mathrm{Cr}$ & 556 & 98.5 & 194 & 260 & 321 \\
\hline $\mathrm{Sc}$ & 23.3 & 19.2 & 3.9 & 18 & 16.2 \\
\hline V & 249 & 299 & 233 & 203 & 195 \\
\hline Cs & 0.4 & 0.6 & 0.8 & 0.2 & 0.4 \\
\hline $\mathrm{Ba}$ & 394 & 248 & 1095 & 310 & 437 \\
\hline $\mathrm{La}$ & 25.4 & 27.5 & 63.2 & 26.2 & 42.3 \\
\hline $\mathrm{Ce}$ & 56.7 & 51.1 & 127.8 & 147.8 & 81.9 \\
\hline $\operatorname{Pr}$ & 7.1 & 7.4 & 15.3 & 6.2 & 9.7 \\
\hline $\mathrm{Nd}$ & 32.5 & 32.9 & 63.3 & 26.6 & 40.1 \\
\hline $\mathrm{Sm}$ & 7.1 & 7.7 & 12.1 & 6.2 & 7.9 \\
\hline $\mathrm{Eu}$ & 2.6 & 2.6 & 4.5 & 2.3 & 2.7 \\
\hline Gd & 6.1 & 6.1 & 9.4 & 5.7 & 6.9 \\
\hline $\mathrm{Tb}$ & 0.9 & 0.9 & 1.2 & 0.9 & 1.0 \\
\hline Dy & 4.5 & 4.8 & 6.6 & 4.6 & 5.4 \\
\hline Но & 0.8 & 1.0 & 1.1 & 0.9 & 1.0 \\
\hline $\mathrm{Er}$ & 1.9 & 2.0 & 2.6 & 2.0 & 2.2 \\
\hline $\mathrm{Tm}$ & 0.3 & 0.3 & 0.3 & 0.3 & 0.3 \\
\hline $\mathrm{Yb}$ & 1.6 & 1.7 & 1.9 & 1.5 & 1.9 \\
\hline $\mathrm{Lu}$ & 0.2 & 0.2 & 0.3 & 0.3 & 0.3 \\
\hline $\mathrm{Hf}$ & 3.8 & 3.8 & 5.2 & 0.9 & 5.7 \\
\hline $\mathrm{Ta}$ & 2.4 & 2.5 & 5.6 & 2.1 & 4.0 \\
\hline $\mathrm{Pb}$ & 2.2 & 1.8 & 4.2 & 1.9 & 2.5 \\
\hline Th & 2.0 & 2.3 & 5.7 & 2.3 & 4.6 \\
\hline $\mathrm{U}$ & 0.6 & 0.6 & 1.5 & 0.4 & 1.2 \\
\hline$\Delta \mathrm{Nb}$ & 0.3 & 0.3 & 0.5 & 0.3 & 0.2 \\
\hline
\end{tabular}




\begin{tabular}{|c|c|c|c|c|c|}
\hline Hawaiite & BA41 & BA42 & BA43 & BA78 & BA86 \\
\hline \multicolumn{6}{|l|}{ Wt. $\%$} \\
\hline $\mathrm{SiO}_{2}$ & 45.86 & 45.14 & 45.65 & 46.19 & 46.14 \\
\hline $\mathrm{TiO}_{2}$ & 3.57 & 3.19 & 2.86 & 2.88 & 2.54 \\
\hline $\mathrm{Al}_{2} \mathrm{O}_{3}$ & 16.84 & 15.78 & 17.31 & 15.29 & 14.82 \\
\hline $\mathrm{Fe}_{2} \mathrm{O}_{3}$ & 13.37 & 12.82 & 11.67 & 12.27 & 12.37 \\
\hline $\mathrm{MnO}$ & 0.16 & 0.21 & 0.2 & 0.19 & 0.18 \\
\hline $\mathrm{MgO}$ & 5.04 & 5.12 & 3.47 & 6.67 & 7.95 \\
\hline $\mathrm{CaO}$ & 7.76 & 8.53 & 8.88 & 8.8 & 8.9 \\
\hline $\mathrm{Na}_{2} \mathrm{O}$ & 3.67 & 3.59 & 4.59 & 3.69 & 3.88 \\
\hline $\mathrm{K}_{2} \mathrm{O}$ & 1.68 & 1.57 & 1.82 & 1.75 & 1.84 \\
\hline $\mathrm{P}_{2} \mathrm{O}_{5}$ & 0.66 & 1.83 & 1.25 & 0.83 & 0.75 \\
\hline LOI & 1.08 & 2 & 1.04 & 1.2 & 0.31 \\
\hline Total & 99.69 & 99.78 & 98.74 & 99.76 & 99.68 \\
\hline $\mathrm{Mg} \#$ & 41 & 42 & 39 & 50 & 54 \\
\hline \multicolumn{6}{|l|}{ ppm } \\
\hline $\mathrm{Nb}$ & 58 & 64.3 & 77.8 & 70.1 & 63.7 \\
\hline $\mathrm{Zr}$ & 284 & 292 & 277 & 292 & 261 \\
\hline Y & 28.5 & 33.6 & 32.5 & 27.6 & 24.5 \\
\hline $\mathrm{Sr}$ & 826 & 1860 & 1154 & 1001 & 813 \\
\hline $\mathrm{Rb}$ & 35.5 & 28.0 & 42.8 & 41.4 & 41.9 \\
\hline $\mathrm{Ga}$ & 23.6 & 21.5 & 22.8 & 22.7 & 22.2 \\
\hline $\mathrm{Ni}$ & 16.8 & 2.4 & 2.16 & 85 & 152 \\
\hline Co & 35.3 & 20.5 & 19.6 & 36.3 & 39.2 \\
\hline $\mathrm{Cr}$ & 8.2 & 3.4 & 1.59 & 172 & 245 \\
\hline $\mathrm{Sc}$ & 14.5 & 14.3 & 13.9 & 15.6 & 16 \\
\hline V & 222 & 155 & 134 & 197 & 189 \\
\hline Cs & 0.3 & 1.1 & 0.5 & 0.5 & 0.4 \\
\hline $\mathrm{Ba}$ & 540 & 977 & 587 & 710 & 695 \\
\hline $\mathrm{La}$ & 46.5 & 60.2 & 61.6 & 55.7 & 50.1 \\
\hline $\mathrm{Ce}$ & 165.6 & 59.4 & 122.3 & 108.7 & 96.7 \\
\hline $\operatorname{Pr}$ & 11.6 & 16.7 & 14.3 & 12.1 & 11.2 \\
\hline $\mathrm{Nd}$ & 47.1 & 72.6 & 57.7 & 50.0 & 45.1 \\
\hline $\mathrm{Sm}$ & 9.2 & 14.3 & 11.1 & 9.3 & 8.9 \\
\hline $\mathrm{Eu}$ & 2.9 & 5.5 & 3.7 & 3.2 & 2.7 \\
\hline Gd & 7.5 & 11.0 & 9.3 & 7.9 & 7.0 \\
\hline $\mathrm{Tb}$ & 1.1 & 1.4 & 1.3 & 1.0 & 1.0 \\
\hline Dy & 6.1 & 7.4 & 6.5 & 6.0 & 5.4 \\
\hline Но & 1.1 & 1.6 & 1.3 & 1.1 & 1.0 \\
\hline $\mathrm{Er}$ & 2.7 & 2.9 & 2.9 & 2.4 & 2.3 \\
\hline $\mathrm{Tm}$ & 0.4 & 0.4 & 0.4 & 0.3 & 0.3 \\
\hline $\mathrm{Yb}$ & 2.3 & 2.3 & 2.7 & 2.1 & 1.9 \\
\hline $\mathrm{Lu}$ & 0.3 & 0.4 & 0.4 & 0.3 & 0.3 \\
\hline $\mathrm{Hf}$ & 1.1 & 1.4 & 6.3 & 6.3 & 6.0 \\
\hline $\mathrm{Ta}$ & 4.3 & 4.9 & 5.9 & 5.1 & 4.5 \\
\hline $\mathrm{Pb}$ & 3.3 & 2.6 & 3.6 & 4.5 & 4.2 \\
\hline Th & 4.6 & 5.0 & 5.6 & 7.1 & 5.7 \\
\hline $\mathrm{U}$ & 1.1 & 1.2 & 1.5 & 1.6 & 1.4 \\
\hline$\Delta \mathrm{Nb}$ & 0.1 & 0.2 & 0.3 & 0.2 & 0.2 \\
\hline
\end{tabular}




\begin{tabular}{|c|c|c|c|c|c|}
\hline Mugearite & BA39 & BA44 & BA74 & BA79 & BA80 \\
\hline \multicolumn{6}{|l|}{ Wt. $\%$} \\
\hline $\mathrm{SiO}_{2}$ & 49.47 & 49.04 & 49.97 & 47.59 & 48.07 \\
\hline $\mathrm{TiO}_{2}$ & 1.89 & 2.13 & 1.6 & 2.06 & 2.04 \\
\hline $\mathrm{Al}_{2} \mathrm{O}_{3}$ & 17.31 & 16.57 & 15.88 & 15.53 & 15.48 \\
\hline $\mathrm{Fe}_{2} \mathrm{O}_{3}$ & 11.94 & 10.67 & 13.56 & 12.19 & 13.11 \\
\hline $\mathrm{MnO}$ & 0.21 & 0.17 & 0.21 & 0.21 & 0.21 \\
\hline $\mathrm{MgO}$ & 2.37 & 3.08 & 2.42 & 2.71 & 3.65 \\
\hline $\mathrm{CaO}$ & 6.54 & 7.08 & 5.12 & 6.17 & 6.05 \\
\hline $\mathrm{Na}_{2} \mathrm{O}$ & 4.93 & 4.34 & 4.82 & 4.85 & 4.72 \\
\hline $\mathrm{K}_{2} \mathrm{O}$ & 2.2 & 2.33 & 2.71 & 2.23 & 2.24 \\
\hline $\mathrm{P}_{2} \mathrm{O}_{5}$ & 0.75 & 0.91 & 1.14 & 1.51 & 1.5 \\
\hline LOI & 1.89 & 3.19 & 2 & 4 & 2 \\
\hline Total & 99.5 & 99.51 & 99.43 & 99.05 & 99.07 \\
\hline $\mathrm{Mg} \#$ & 27 & 35 & 25 & 29 & 34 \\
\hline \multicolumn{6}{|l|}{ ppm } \\
\hline $\mathrm{Nb}$ & 67.3 & 71.1 & 79.9 & 74 & 75.4 \\
\hline $\mathrm{Zr}$ & 409 & 347 & 432 & 374 & 406 \\
\hline Y & 30.5 & 34.4 & 40.9 & 44.9 & 44.1 \\
\hline $\mathrm{Sr}$ & 892 & 1061 & 939 & 762 & 750 \\
\hline $\mathrm{Rb}$ & 53.8 & 48.9 & 41.8 & 32.4 & 30.7 \\
\hline $\mathrm{Ga}$ & 26.4 & 24 & 24.5 & 9.7 & 9.8 \\
\hline $\mathrm{Ni}$ & 4.4 & 15.4 & 1.5 & 3 & 2.2 \\
\hline Co & 18.3 & 18.1 & 9.7 & 15.8 & 15.1 \\
\hline $\mathrm{Cr}$ & 6.3 & 17.1 & 1.8 & 6.3 & 5.1 \\
\hline $\mathrm{Sc}$ & 9.5 & 15.3 & 12.6 & 10.6 & 10.8 \\
\hline V & 79 & 97.2 & 5.3 & 45.3 & 44.9 \\
\hline Cs & 0.5 & 0.6 & 0.4 & 0.3 & 0.7 \\
\hline $\mathrm{Ba}$ & 1064 & 1233 & 1296 & 658 & 645 \\
\hline $\mathrm{La}$ & 59.4 & 74.2 & 77.3 & 74.1 & 73.3 \\
\hline $\mathrm{Ce}$ & 121.1 & 151.7 & 122.3 & 96.5 & 132.2 \\
\hline $\operatorname{Pr}$ & 12.9 & 17.9 & 20.4 & 19.2 & 19.4 \\
\hline $\mathrm{Nd}$ & 50.7 & 73.6 & 84.8 & 85.2 & 82.9 \\
\hline $\mathrm{Sm}$ & 9.4 & 13.1 & 15.3 & 16.3 & 16.4 \\
\hline $\mathrm{Eu}$ & 3.2 & 4.6 & 5.8 & 5.2 & 5.2 \\
\hline Gd & 7.7 & 11.0 & 12.0 & 13.7 & 13.6 \\
\hline $\mathrm{Tb}$ & 1.2 & 1.5 & 1.7 & 1.8 & 1.9 \\
\hline Dy & 6.0 & 7.3 & 8.4 & 9.7 & 9.8 \\
\hline Ho & 1.2 & 1.4 & 1.6 & 1.9 & 1.9 \\
\hline $\mathrm{Er}$ & 3.0 & 3.1 & 3.7 & 4.0 & 3.9 \\
\hline $\mathrm{Tm}$ & 0.4 & 0.5 & 0.5 & 0.6 & 0.6 \\
\hline $\mathrm{Yb}$ & 2.6 & 2.9 & 3.2 & 3.5 & 3.5 \\
\hline $\mathrm{Lu}$ & 0.4 & 0.5 & 0.5 & 0.5 & 0.5 \\
\hline $\mathrm{Hf}$ & 1.2 & 8.6 & 1.6 & 8.9 & 9.2 \\
\hline $\mathrm{Ta}$ & 5.0 & 5.5 & 5.8 & 8.9 & 9.2 \\
\hline $\mathrm{Pb}$ & 5.5 & 7. & 5.0 & 4.8 & 5.0 \\
\hline Th & 7.4 & 6.1 & 7.1 & 6.5 & 6.4 \\
\hline $\mathrm{U}$ & 1.8 & 1.7 & 1.6 & 1.6 & 1.5 \\
\hline$\Delta \mathrm{Nb}$ & -0.08 & 0.1 & 0.1 & 0.2 & 0.1 \\
\hline
\end{tabular}


$\left.\mathrm{Mg \#}=100 *(\mathrm{MgO} / 40.31) /(\mathrm{MgO} / 40.31)+\mathrm{Fe}_{2} \mathrm{O}_{3} * 0.8998 /(71.85 *(1-0.15))\right)$, assuming

$\mathrm{Fe}_{2} \mathrm{O}_{3} /\left(\mathrm{Fe}_{2} \mathrm{O}_{3}+\mathrm{FeO}\right)=0.15$. Recalculated to $100 \%$ anhydrous; total iron is expressed as $\mathrm{Fe}_{2} \mathrm{O}_{3}$; LOI: Loss on ignition. 
Table 3: K-Ar ages obtained on some mafic rocks from the Bamenda area.

\begin{tabular}{|c|c|c|c|c|c|c|c|}
\hline Sample & Rock & $\mathrm{K}_{2} \mathrm{O}(\%)$ & ${ }^{40} \mathrm{Ar}^{*}\left(10^{15} \mathrm{at} / \mathrm{g}\right)$ & ${ }^{40} \mathrm{Ar}^{*}\left(10^{-6} \mathrm{~cm}^{3} / \mathrm{g}\right)$ & Age (Ma) & Error (1s) & Laboratory \\
\hline BA61 & Basalt & 1.19 & 0 & 0 & 0 & 0 & CRPG (Nancy) \\
\hline BA31 & Basanite & 1.65 & 0.0006 & 0.021 & 0.4 & 0.1 & CRPG (Nancy) \\
\hline BA10 & Basanite & 1.52 & 0.00189 & n.a & 1.2 & 0.2 & CRPG (Nancy) \\
\hline BA24 & Basanite & 1.91 & 0.0021 & 0.079 & 1.3 & 0.1 & CRPG (Nancy) \\
\hline BA73 & Basanite & 2.016 & 0.0076 & 0.282 & 5.5 & 0.4 & CRPG (Nancy) \\
\hline BA37 & Basanite & 1.31 & 0.0086 & 0.322 & 7.6 & 0.2 & CRPG (Nancy) \\
\hline BA68 & Basanite & 1.72 & 0.0124 & 0.462 & 8.3 & 0.3 & CRPG (Nancy) \\
\hline BA42 & Hawaiite & 1.6 & 0.0236 & 0.877 & 16.9 & 0.3 & CRPG (Nancy) \\
\hline BA60 & Hawaiite & 1.91 & 0.03525 & n.a. & 17.6 & 0.3 & CRPG (Nancy) \\
\hline BA60 & Duplicate & & 0.0351 & n.a. & 17.4 & 0.8 & CRPG (Nancy) \\
\hline Sample & Rock & $\mathrm{K}_{2} \mathrm{O}(\%)$ & ${ }^{40} \mathrm{Ar} *(\%)$ & ${ }^{40} \mathrm{Ar}^{*}\left(10^{-12} \mathrm{~mol} / \mathrm{g}\right)$ & Age (Ma) & Error (1s) & Laboratory \\
\hline BA87 & Basalt & 0.63 & 8.48 & 4.011 & 4.4 & 1.4 & Univ. Queensland(Australia) \\
\hline
\end{tabular}

The following decay constants were used: ${ }^{40} \lambda \mathrm{e}=0.581 \times 10^{-10} \mathrm{a}^{-1}$ and ${ }^{40} \lambda_{\beta}=4.962 \times 10^{-10} \mathrm{a}^{-1}$. n.a.: not available. 
Table 4. Sr-Nd-Pb isotopic compositions of the rocks fron Bamenda Mountains. na: not analysed.

\begin{tabular}{cccccccc}
\hline Sample & Rock type & ${ }^{87} \mathrm{Sr} /{ }^{86} \mathrm{Sr}$ & ${ }^{143} \mathrm{Nd} /{ }^{144} \mathrm{Nd}$ & $\varepsilon \mathrm{Nd}$ & ${ }^{206} \mathrm{~Pb} /{ }^{204} \mathrm{~Pb}$ & ${ }^{207} \mathrm{~Pb} /{ }^{204} \mathrm{~Pb}$ & ${ }^{208} \mathrm{~Pb} /{ }^{204} \mathrm{~Pb}$ \\
\hline BA10 & Basanite & 0.703078 & 0.512895 & 5.01 & na & na & na \\
BA24 & Basanite & 0.703138 & 0.512852 & 4.17 & na & na & na \\
BA46 & Basanite & 0.703352 & 0.512890 & 4.92 & 20.217 & 15.645 & 39.729 \\
BA47 & Basanite & 0.703338 & 0.512886 & 4.84 & 20.250 & 15.645 & 39.751 \\
BA52 & Basanite & 0.703505 & 0.512812 & 3.39 & na & na & na \\
BA68 & Basanite & 0.703702 & 0.512797 & 3.10 & 19.417 & 15.616 & 39.302 \\
BA84 & Basanite & 0.703767 & 0.512828 & 3.71 & 19.591 & 15.536 & 38.537 \\
BA11 & Basalt & 0.703340 & 0.512860 & 4.33 & na & na & na \\
BA27 & Basalt & 0.703935 & 0.512757 & 2.32 & na & na & na \\
BA65 & Basalt & 0.704120 & na & na & na & na & na \\
BA87 & Basalt & 0.703375 & 0.512898 & 5.07 & na & na & na \\
BA88 & Basalt & 0.703070 & 0.512911 & 5.33 & na & na & na \\
BA06 & Hawaiite & 0.703029 & 0.512927 & 5.64 & na & na & na \\
BA41 & Hawaiite & 0.703557 & 0.512733 & 1.85 & 18.198 & 15.461 & 37.805 \\
BA42 & Hawaiite & 0.704133 & 0.512743 & 2.05 & na & na & na \\
BA56 & Hawaiite & 0.703951 & 0.512795 & 3.06 & 19.131 & 15.568 & 39.058 \\
BA60 & Hawaiite & 0.704243 & 0.512616 & -0.43 & 17.317 & 15.422 & 37.114 \\
BA66 & Hawaiite & 0.703949 & 0.512761 & 2.40 & Na & na & na \\
BA77 & Hawaiite & 0.703945 & 0.512820 & 3.55 & 19.494 & 15.601 & 39.682 \\
BA78 & Hawaiite & 0.703945 & na & na & 18.921 & 15.536 & 38.537 \\
BA86 & Hawaiite & 0.703387 & 0.512809 & 3.34 & na & na & na \\
BA39 & Mugearite & 0.704031 & 0.512755 & 2.28 & na & na & na \\
BA79 & Mugearite & 0.703803 & 0.512769 & 2.56 & na & na & na \\
\hline
\end{tabular}


Representative microprobe analyses of olivine from selected lavas from Bamenda area.

Sample

$\begin{array}{cc} & \text { Basanite } \\ & \mathrm{r} \\ \mathrm{SiO}_{2} & 36.65 \\ \mathrm{TiO}_{2} & 0.07 \\ \mathrm{Al}_{2} \mathrm{O}_{3} & 0.00 \\ \mathrm{FeO} & 30.23 \\ \mathrm{MnO} & 0.72 \\ \mathrm{MgO} & 32.11 \\ \mathrm{CaO} & 0.50 \\ \mathrm{NiO} & 0.00 \\ \mathrm{Cr}_{2} \mathrm{O}_{3} & 0.02 \\ \mathrm{Total} & 100.30\end{array}$

Formulae on basis of 4 oxygens

$\begin{array}{ll}\mathrm{Si} & 0.99\end{array}$

$\mathrm{Fe}^{2+} \quad 0.68$

Mn $\quad 0.02$

$\mathrm{Mg} \quad 1.30$

$\mathrm{Ca} \quad 0.01$

$\mathrm{Ni} \quad 0.00$

$\mathrm{X}_{\mathrm{Mg}} \quad 0.65$

Fo $\quad 65.44$

$\mathrm{r}=\mathrm{rim} ; \mathrm{c}=$ core $; \mathrm{m}=$ microlite c

\begin{tabular}{rc}
\multicolumn{1}{c}{$c$} & xenocryst \\
39.55 & 40.84 \\
0.00 & 0.09 \\
0.03 & 0.03 \\
16.84 & 9.21 \\
0.23 & 0.10 \\
42.52 & 48.83 \\
0.11 & 0.10 \\
0.28 & 0.32 \\
0.03 & 0.06 \\
99.59 & 99.58
\end{tabular}

$\begin{array}{rr}1.01 & 1.00 \\ 0.36 & 0.19 \\ 0.00 & 0.00 \\ 1.61 & 1.79 \\ 0.00 & 0.00 \\ 0.01 & 0.01 \\ 0.82 & 0.90\end{array}$

81.82

90.43

$\mathrm{m}$
37.35
0.05
0.00
28.43
0.54
33.62
0.35
0.00
0.00
100.34

BA37

\subsection{0}

0.64

0.01

1.34

0.01

0.00

0.68

67.83

83.81

$\mathrm{c}$
39.81

$\mathrm{r}$

$0.00-0.05$

$0.08 \quad 0.00$

$15.17 \quad 23.56$

$\begin{array}{ll}0.08 & 0.39\end{array}$

$44.06 \quad 37.03$

$\begin{array}{ll}0.25 & 0.47\end{array}$

$0.07 \quad 0.00$

$0.00 \quad 0.00$

$99.52 \quad 100.13$

$\begin{array}{ll}1.00 & 1.01 \\ 0.32 & 0.51 \\ 0.00 & 0.01 \\ 1.66 & 1.44 \\ 0.01 & 0.01 \\ 0.00 & 0.00 \\ 0.84 & 0.74\end{array}$

1.01
0.51
0.01
1.44
0.01
0.00
0.74

73.70 